\title{
CERCETĂRI ARHEOLOGICE ÎN VATRA ORAŞULUI DE FLOCI, (PIUA PETRI), COMUNA GIURGENI, JUDEŢUL IALOMIŢA. Campaniile din anii 2006-2007
}

Anca Păunescu, Irina Ene, Dana Mihai, Gheorghe Matei, Gabriel Vasile

\section{RECHERCHES ARCHÉOLOGIQUES DANS LE CENTRE DE ORAŞUL DE FLOCI (PIUA PETRI), COMMUNE GIURGENI, DÉPARTEMENT DE IALOMIŢA. Les campagnes 2006-2007}

Dans cet article les auteurs se propose à présenter les résultats des fouilles des années 2006-2007 du centre de l'établissement urbain du moyen âge de Oraşul de Floci, commune Giurgeni, département de la Ialomiţa. Les fouilles ont été faites dans plusieurs secteurs du site, ayant comme objectif les suivants :

- Secteur Grind no. 1 - on a suivi comme paravent la densité, la disposition et les phases de construction des habitations des $\mathrm{XVI}^{\mathrm{e}}-\mathrm{XVII}{ }^{\mathrm{e}}$ siècles.

- Secteur Grind no. 2 - pour bâtir une construction à la limite du nord du secteur, où on pense constituer un micro-musée et une base archéologique du site, on a fouillé trois sections comme sondage pour épuiser du point de vue archéologique une surface de 200 m.c.

- Secteur Grind no. 3 - on a continué les recherches pour surprendre les relations entre les habitations ayant plusieurs phases de refaites de la deuxième moitié du $\mathrm{XV}^{\mathrm{e}}$ siècle et jusqu'au $\mathrm{XVII}^{\mathrm{e}}$ siècle et de même a trouver la limite d'est de la nécropole no. 3 . no. 1".

- Secteur Grind no. 6 - ici on a fait des travaux de conservation primaire du monument "L'Eglise

- Secteur Grind no. 8 - on a fouillé trois sections pour vérifier les données des prospections géomagnetiques.

- Secteur Grind no. 9 - par la section do 3 on a continué a vérifier les dates des prospections archéogéophysiques de l'année 2003 faites par le BCUM de Alba Iulia.

Mots clefs : établissement urbain du moyen âge, habitations, nécropoles, $\mathrm{XVI}^{\mathrm{e}}-\mathrm{XVIII}{ }^{\mathrm{e}}$ siècles

Cuvinte cheie: aşezare urbană medievală, locuinţe, necropole, secolele XVI-XVII

Desfăşurarea cercetărilor arheologice în campaniile din anii 2006-2007 s-a concentrat pe Grindurile 1 şi 3 Avicola, cu scopul de a investiga şi urmări densitatea şi dispunerea locuinţelor în raport cu biserica nr. 2 (Grindul nr. 1) şi respectiv necropola nr. 3 (Grindul nr. 3). Totodată s-a continuat şi verificarea arheologică a informaţiilor furnizate de prospecţiile arheogeofizice pe Grindurile nr. 8 şi 9.

\section{Sector Grind 1.}

În cursul campaniilor din anii 2006 şi 2007 s-au continuat cercetările în limita nordică a grindului nr. 1 (planşa 1), în zona unde anterior au fost identificate şi dezvelite integral două locuinţe, cu aceeaşi orientare, şi cu plan dreptunghiular, compartimentate în două încăperi, inegale ca dimensiuni (Păunescu et alii 2006).

Încă din anul 2005 au fost trasate 2 casete cu dimensiuni egale $(5 \times 5 \mathrm{~m})$ în apcandropierea 
locuinţei 1 cu pavaj exterior din bolovani de piatră (S.I B/2003), într-o zonă unde, sub arătură, se desena o suprafaţă de pământ amestecat cu mult cărbune, bulgări mari de chirpic ars roşucafeniu, fragmente de oase de animale şi numeroase fragmente de vase ceramice nesmălţuite şi mici fragmente provenite de la cahle de sobă. După îndepărtarea acestui strat, în caseta 2/2005 a fost surprinsă o parte din podeaua de lut a unei locuințe şi urmele a câtorva găuri de pari. Din cauza vremii nefavorabile cercetarea nu a mai putut fi continuată şi a fost reluată în vara anului 2006. Pentru a surprinde limitele şi planul locuinţei au mai fost trasate casetele $\mathrm{nr} .3$ şi $5(8 \times 2 \mathrm{~m})$ cu un martor de $1 \mathrm{~m}$ între ele, paralele cu latura de vest a casetei nr. 2 şi caseta nr. $4(10 \times 3 \mathrm{~m})$, paralelă cu latura de est a casetei nr. 5 păstrându-se un martor lat de $0,50 \mathrm{~m}$ (planşa 2).

Stratul de pământ arat conţinea foarte multe fragmente de ceramică nesmălţuită şi câteva fragmente mărunte de buze de farfurii smălţuite specifice secolelor XVI-XVII, fragmente de cahlă-placă, datate în a doua jumătate a secolului al XVI-lea, care aparţin tipului decorat cu un cavaler călare (Chițescu et alii 1981), spărturi de cărămidă, fragmente de oase de animale şi o monedă (dinar, Ungaria, 1550). Tot în acest strat s-au descoperit, într-o mică groapă din caseta nr. 2 , fragmentele unei oale borcan, care a putut fi întregită, parţial smălţuită, pe care o vom prezenta mai jos.

După îndepărtarea acestui nivel, la adâncimea de cca. $0,60 \mathrm{~m}$, în suprafaţa casetei nr. 2 s-a aflat un strat de lut de nivelare, cu o grosime de aproximativ 0,10 $\mathrm{m}$, întrerupt în unele locuri de dărâmătură compactă formată din bulgări de chirpic puternic ars. Sub acest strat de nivelare în suprafaţa casetelor, la adâncimea de $0,90 \mathrm{~m}$, s-a desenat conturul podelei unei locuinţe (complex 2) şi a cinci gropi rotunde, puţin adâncite (complexele 3-5, 9, 10) aflate în apropierea laturii de nord-vest. Podeaua locuinţei, delimitată de lăcaşul bârnelor-talpă, se încadra într-un plan dreptunghiular cu laturile lungi $(5,60 \mathrm{~m})$ orientate sud-est, iar laturile scurte $(4,40 \mathrm{~m})$ erau orientate nordvest. Aproape de colţul nordic al podelei se mai păstra soclul dreptunghiular din lut ars la roşu al unei sobe, înalt de $0,20 \mathrm{~m}$, iar lângă acesta se afla un fragment de bârnă groasă, carbonizată, probabil o grindă prăbuşită din acoperişul locuinţei. Pe suprafaţa soclului s-a observat urma unei găuri de par subţire $\mathrm{cu}$ diametrul de $0,05 \mathrm{~m}$. Paralel cu lungimea laturii de NV, la o distanţă de $0,70 \mathrm{~m}$ de ea spre interior, s-a aflat un şir de gropi de pari subţiri $(\mathrm{d}=0,10 \mathrm{~m})$, care poate au susţinut $\mathrm{o}$ laviţă din scânduri adosată peretelui. Pe suprafaţa podelei spre centrul ei, s-au mai aflat şi alte câteva gropi de pari subţiri, grupate dezordonat. În colţul de vest al podelei se aflau alte două gropi apropiate, $\mathrm{cu}$ diametrul de 0,40 m, adânci de 0,20 m. Alte gropi similare s-au aflat aproape de colţul sudic şi aproape de mijlocul laturii de sud-est (planşa 3). Pe suprafaţa podelei au fost descoperite puţine fragmente ceramice mărunte, seminţe carbonizate şi în apropierea soclului din lut al sobei câteva fragmente de ţesătură de lână carbonizate. Lipsa de inventar arheologic presupune că locuinţa a fost abandonată deliberat înainte de distrugerea ei prin incendiu.

În limita exterioară a laturii de $\mathrm{NV}$ a locuinţei din suprafaţa casetei $2 / 2005$ s-a observat, la adâncimea de $-1,05 \mathrm{~m}$, traseul unei bârne-talpă, puţin adâncită într-un strat de nivelare din lut galben-cenuşiu, care părea o prelungire a laturii de SV a locuinţei. La distanţă de $1 \mathrm{~m}$ spre nord de lăcaşul acestei bârne s-au aflat resturile unui cuptor cu pilon central din lut cruțat, pentru arderea ceramicii (complex nr. 6), care a fost distrus din vechime. În apropiere de conturul gropii cuptorului $(\mathrm{d}=2 \mathrm{~m})$ s-au observat 10 gropi de pari subţiri, oarecum aliniate care probabil susţineau o laviţă (planşa 4). Toate aceste elemente ne îndeamnă să formulăm ipoteza că locuinţa mai sus descrisă ar fi aparţinut unui meşter olar, al cărui "atelier" era amenajat mai rudimentar. Analiza 
materialului ceramic pe care-l vom prezenta în continuare şi monedele descoperite susţin datarea acestui complex în prima jumătate a secolului al XVI-lea.

Al doilea cuptor (complex nr. 7) fost cercetat în caseta nr. 3. Pe profilul vestic al casetei cât şi în suprafaţa secţiunii, imediat după îndepărtarea stratului de pământ vegetal s-a conturat o groapă cu diametrul de cca. 2 m, care a străpuns nivelul de locuire incendiat. Această groapă a fost căpăcuită cu un strat gros de lut galben, compact, cu grosimea de $0,30 \mathrm{~m}$. După înlăturarea plăcii din lut, la adâncimea de $-1 \mathrm{~m}$ a apărut suprafaţa unei podele din lut galben-cenuşiu, în care se adâncea jumătate din groapa cuptorului, de asemenea distrus din vechime. Restul se afla în peretele vestic al secţiunii. Pe podea s-au aflat două şiruri de gropi de pari subţiri aliniaţi cu limita nordică a cuptorului. În groapa cuptorului de ars ceramica s-au găsit bulgări mari de chirpic ars proveniţi de la pereţi şi cupola lui, împreună cu fragmente ceramice foarte mici. S-a mai păstrat puţin din baza pilonului central şi multă cenuşă fină amestecată cu pigment de cărbune. Gura de alimentare se afla în peretele estic al casetei. Deoarece, aşa cum s-a văzut pe profilul estic al casetei, groapa cuptorului începe să se contureze sub stratul de pământ vegetal, propunem datarea funcţionării acestui complex în cursul secolului al XVII-lea.

Caseta nr. 1 (planşa 2) a fost trasată încă din cursul campaniei de cercetări din anul 2005 la distanţă de $1 \mathrm{~m}$ spre nord faţă de colţul nord-vestic al casetei nr. 2. Imediat după îndepărtarea stratului de pământ vegetal, pe întreaga suprafaţă a casetei a apărut un strat de pământ afânat, în care s-au găsit foarte multe oase de animle, fragmente de vase ceramice predominant nesmălţuite, fragmente mărunte de cahle acoperite $\mathrm{cu}$ smalţ de culoare verde, şi câteva fragmente foarte mici de ceramică otomană. Consistenţa acestui strat, care coboară până la adâncimea de $0,75 \mathrm{~m}$, are aspectul asemănător cu cea a gropilor de depunere a reziduurilor menajere descoperite şi cercetate în cursul campaniilor anterioare. Limitele acestei gropi s-au îngustat spre fund, când la adâncimea de $1,20 \mathrm{~m}$ a apărut stratul de pământ lutos, steril din punct de vedere arheologic. Singura piesă care a fost recuperată este $o$ farfurie smălţuită, caracteristică ceramicii din secolul al XVIIlea, pe care o vom prezenta în rândurile de mai jos referitoare la descrierea ceramicii.

În cursul campaniei de cercetări arheologice din vara anului 2007, s-a dezvelit o nouă suprafaţă în limita nord-estică a locuinţei mai sus descrisă, unde se afla o zonă întinsă de chirpic ars şi cărbune, răscolit de arătură. Au fost trasate casetele nr. $6(7 \times 3 \mathrm{~m})$, nr. $7(8 \times 3 \mathrm{~m})$, paralele, orientate nord-sud, cu un martor lat de $1 \mathrm{~m}$ între ele.

După îndepărtarea stratului de pământ arat în care s-au descoperit 3 monede din secolele XVI-XVII ${ }^{1}$, şi o mărgică de la un cercel de tâmplă, specific secolului al XVI-lea (Rosetti 1972). La adâncimea de $-0,55 \mathrm{~m}$ a apărut suprafaţa de chirpic ars, răspândită pe podeaua din lut a locuinţei L.1/2007 (complex nr. 1). Această podea acoperă jumătatea sudică a suprafeţei casetelor 6 şi 7 . După înlăturarea bulgărilor de chirpic ars pe suprafaţa podelei a fost descoperită o piatră rotundă de râşniţă, perforată în centru, şi s-au conturat lăcaşurile bârnelor-talpă, adâncite în lutul podelei, care delimitau planul locuinţei. Aproape de colţul de nord, lăcaşul bârneitalpă al laturii de nord-est a fost perforat de o groapă târzie (complex nr. 6) în care au fost aruncate oasele unor animale de talie mare (bovine) (planşa 5).

În capătul nordic al casetei nr. 7, la o distanţă de $1,50 \mathrm{~m}$ de latura de nord-est a locuinţei, s-a descoperit un şir de bolovani prinşi într-un strat de dărâmătură de chirpic, cu o orientare asemănătoare laturii de nordest, ce mărgineau spre sud lăcaşul unei bârne talpă, în care se mai păstrau fragmente din

\footnotetext{
${ }^{1}$ Două exemplare dinari, Ungaria, Vladislav II (14901516) şi o para (fals) Imperiul Otoman, Ahmed I (1603-1617). Mulţumim şi pe această cale domnului Mihai Dima pentru determinarea monedelor.
} 
lemnul carbonizat (complex nr. 2), şi spre nord o groapă pentru depunerea rezidurilor menajere (complex nr. 5) Inventarul acestei gropi conţinea o mare cantitate de oase de provenite de la animale de talie mare, oase de peşte, spărturi de cărămidă, pietre şi puţine fragmente ceramice neîntregibile. După aspect şi dimensiuni, bolovanii se aseamănă cu cei folosiţi pentru amenajarea pavajului din exteriorul locuinței nr. 1/2003 (Păunescu et alii 2006). La adâncimea de $-0,40 \mathrm{~m}$, în pământul dintre bolovani s-a descoperit un alt $\operatorname{dinar}^{2}$ din secolul al XVI-lea. Pentru a surprinde întreaga întindere a podelei a mai fost trasată caseta nr. $8(9 \times 1,5 \mathrm{~m})$, paralelă cu latura de est a casetei nr.7, păstrându-se un martor de 0,50 m între ele. Dimensiunile aproximative ale locuinţei nr. 1/2007 (complex nr. 1) sunt $6,25 \times 4,50$ m. Şi în acest caz, planul locuinţei a fost rectangular, $\mathrm{cu}$ laturile orientate sud-est nord-vest. Podeaua din lut a acestei locuinţe care era foarte subţire a fost aşezată peste un strat de pământ grăunţos, amestecat, în care s-au găsit foarte multe oase şi solzi de peşte, un fragment de ceramică otomană (Iznik), 2 monede $^{3}$ şi fragmente de ceramică de uz nesmălţuită neîntregibile, ce aparţineau mai ales formei de oală cu toartă, nesmălţuită de diverse dimensiuni. Cele două monede, descoperite în stratul de pământ grăunţos de sub podeaua din lut, indică datarea construirii locuinţei nr. 1/2007 (complex nr. 1) în primele decenii ale secolului al XVII-lea.

După îndepărtarea acestui strat, la adâncimea de $-0,80 \mathrm{~m}$, în suprafaţa casetelor 7 şi 8 a apărut un alt strat de lutuială cu urme de arsură, bulgări mici de chirpic ars roşucafeniu, pigment de cărbune şi un şir de 5 gropi de pari subţiri la o distanţă de $0,50 \mathrm{~m}$ de şirul de bolovani de piatră (complex nr. 10). Pe suprafaţa podelei s-a descoperit o piesă conică din os, un fragment dintr-o amuletă

\footnotetext{
${ }^{2}$ Ungaria, emitent neprecizat, sec. XVI, dinar (fals).

${ }^{3}$ Dinar (fals) Ungaria, Ferdinand I, (1526-1564), şi un aspru, Imperiul Otoman, emitent neprecizat, sec. XVIXVII.
}

din piatră şi un inel din bronz. În capătul sudic al casetei nr. 6, la adâncimea de $-0,93$ $m$ faţă de nivelul actual de călcare, s-a observat urma unei vetre din lut ars-roşu în care se afla o gaură de par. Toate aceste elemente aparţin unei locuinţe (L. 2/2007complex nr. 10), distrusă tot de un incendiu, ale cărui resturi au fost curăţate şi nivelate. Cota de adâncime la care a fost descoperită sugerează faptul că ea a fost contemporană cu L1/2006, descrisă mai sus. Se constată că şirul de bolovani de piatră a fost amenajat după dezafectarea locuinţei nr. 2/2007, pe dărâmătura acesteia, fără să putem preciza scopul. Lângă şirul de pietre, în dărâmătură sa găsit o mărgică din sticlă colorată.

În concluzie, datele rezultate din cercetarea integrală a locuinţelor descoperite în acest sector ne îndreptăţesc să constatăm că ele au fost distruse de incendii, la mijlocul secolului al XVI-lea şi în primele decenii ale secolului al XVII-lea. De fiecare dată, după incendiere, dărâmătura de chirpic ars şi cărbune a fost nivelată şi superficial căpăcuită de un strat de lut care de fapt a fost utilizat ulterior ca podea pentru o nouă fază de refacere a unei locuinţe, cu aceeaşi orientare. Acestă observaţie poate fi constatată şi în cazul locuinţelor descoperite şi cercetate în sectorul grindului nr. 3. Dar această situaţie face foarte dificilă surprinderea în planul aşezării a traseului unei străzi - calea publică -, care este elementul esenţial într-o aşezare urbană.

\section{Inventarul arheologic.}

În privinţa categoriilor de piese descoperite în inventarul complexelor cercetate considerăm importantă prezentarea unor categorii ceramice ce contribuie la o mai bună cunoaştere a elementelor de cultură materială în mediul urban medieval din Țara Românească.

Materialul ceramic aparţinând în general secolelor XVI şi XVII este reprezentat, în linii mari, de formele obişnuite - nesmălţuite sau smălţuite -, motiv pentru care ne vom opri 
doar asupra prezentării unor piese întregi sau întregite, de factură locală şi ceramică de import.

În cadrul ceramicii de uz nesmălţuite forma cea mai frecvent întâlnită este a oalei cu toartă, specifică secolului al XVI-lea, lucrată din pastă fină, roşie, bine arsă, cu pereţii subţiri, buza uşor evazată cu marginea rotunjită, corpul bombat, fundul drept. Toarta arcuită, ovală în secțiune, se prinde de marginea exterioară a buzei şi în zona de maximă arcuire a pereţilor vasului. $\mathrm{Pe}$ marginea exterioară a buzei este decorată fie cu 2-3 linii paralele incizate, fie cu linii paralele trasate cu vopsea albă (planşa 6, fig. $1,2,3)$.

În număr mai redus, în stare fragmentară, se găseşte forma ulcioarelor, specifice secolelor XV-XVI, lucrate din pastă fină, de culoare roşie, decorate pe umăr cu benzi de linii paralele incizate şi pe corp cu linii oblice lustruite (planşa 6, fig. 4).

Mai menţionăm descoperirea în caseta nr. 2/2006 a unei căni cu picior şi cu toartă, lucrată din pastă roşie-gălbuie, cu pereţii mai groşi, cu gâtul înalt, evazat şi buza scurtă cu marginea rotunjită, cu corpul bombat sprijinit pe un picior înalt, profilat. Toarta se prinde sub muchia buzei şi în zona de maximă arcuire a pereţilor vasului. Vasul era ornamentat pe umăr cu trei linii paralele incizate (planşa 6, fig. 5). Alte fragmente ce aparţin acestei forme de vas, de asemenea specifice ceramicii din secolul al XVI-lea, sau mai găsit şi în inventarul unor gropi pentru depozitarea reziduurilor menajere.

Ceramica smălţuită este reprezentată prin numeroase fragmente de farfurii sau castroane cu picior inelar şi ornamentate $\mathrm{cu}$ variate motive geometrice sau florale, acoperite cu smalţ de diverse culori sau nuanţe. Un exemplar deosebit este forma strachinei descoperită în caseta nr. 2/2006, lucrată din pastă fină, de culoare roz-gălbui. Pereţii vasului sunt larg arcuiţi, cu marginea ridicată vertical şi rotunjită şi baza inelară. Suprafaţa interioară a vasului, acoperită cu smalţ de culoare galben închis este decorată în tehnica sgrafitto cu registre de linii vălurite şi ove (planşa 7, fig. 1). Atât prin formă cât şi prin tehnica decorului, acest vas aparţine secolelor XV şi XVI. Cele mai apropiate analogii în vederea datării le găsim în ceramica descoperită la Curtea-Veche din Bucureşti (Rosetti 1959).

Farfuriile sunt reprezentate prin două exemplare întregite, diferite însă din punct de vedere a formei şi tehnicii de realizare a decorului. Farfuria descoperită în anul 2006 avea pereţii larg evazaţi, cu marginea rotunjită şi picior inelar. Suprafaţa interioară a fost decorată cu două cercuri concentrice formate din pete de culoare albă, distanţate, acoperite cu un smalţ de culoare verde. A doua farfurie, descoperită în inventarul gropii pentru depozitarea reziduurilor menajere din caseta $1 / 2006$, este lucrată dintr-o pastă fină, cu foarte puţin nisip în amestec, de culoare galbui roşcat, bine arsă. Vasul are fundul drept, cu pereţii mult evazaţi, cu marginea tăiată oblic spre exterior. Pe suprafaţa interioară a vasului se observă o muchie profilată. Decorul este format din grupuri de motive florale, dispuse distanţat pe pereţii farfuriei şi în centru. Întrega suprafaţă a fost acoperită cu un smalţ roşu cărămiziu (planşa 7, fig. 2). Atât prin tehnica de execuţie, cât şi prin decor această farfurie se aseamănă cu cele descoperite în jurul cuptoarelor de olari de pe Grindul nr. 2 din vatra oraşului, care au fost datate la mijlocul secolului al XVII-lea (Păunescu, 1998-2000).

Ceramica ornamentală este reprezentată prin câteva fragmente de cahleplacă de sobă, decorate cu motive geometrice şi acoperite cu smalţ de culoare verde închis. Unele dintre ele par să provină de la cahleleplacă decorate cu un cavaler călare, datate în cursul secolelor XVI-XVII (Chiţescu et alii 1981). Acelaşi tip de cahle, datate în secolul al XVII-lea, au fost descoperite şi în cursul cercetărilor arheologice de pe dealul Mihai Vodă din Bucureşti (Cantea 1959). 
Ceramica de import este reprezentată în special de mici fragmente provenite de la diferite forme de vase de porţelan (cupe, boluri sau farfurii) produse la Iznik decorate cu motive vegetale. Ele au fost descoperite atât în nivelele de dărâmătură ale locuinţelor distruse prin incendii, cât şi în inventarul gropilor pentru depunerea reziduurilor menajere.

Deosebite sunt următoarele vase care arată că meșterii olarii locali fie au imitat unele forme ale ceramicii otomane provenită din atelierele de la Iznik, care au fost decorate cu motive frecvent întâlnite în ceramica smălţuită locală, fie au decorat forme de vase uzuale cu motive decorative ale ceramicii otomane.

Supunem atenţiei fragmentul care provine de la o cană înaltă, uşor tronconică, lucrată din pastă de culoare cărămizie, cu pereţii mai groşi spre linia fundului, cu fundul drept, cu muchia buzei rotunjită şi cu o toartă groasă, dreaptă, paralelă cu peretele vasului, cu secţiune dreptunghiulară, care se prinde sub buză şi aproape de linia fundului. Suprafaţa exterioară a vasului, a fost decorată cu triunghiuri trasate cu vârful spre baza vasului. Spaţiul delimitat de laturile trunghiului a fost umplut cu mai multe registre de linii în val, incizate, peste care au fost aplicate pete de smalt verde-oliv şi galben deschis (planşa 7, fig. 3).

Fragmente de vase cilindrice, fără toartă, acoperite cu smalţ monocrom, verdeoliv sau galben, au mai fost descoperite şi în inventarul altor complexe arheologice din aria sitului. În cazul de față, cana cu toartă imită forma cănilor cilindrice, cu toarta mică, dreptunghiulară, aplicată în zona de mijloc a peretelui vasului, decorate cu motive florale, produse în atelierele ceramice din a doua jumătate a secolului al XVI-lea de la Iznik. Ele erau folosite ca stacane pentru băutul berii (Aslanapa 2006).

O piesă aparte o reprezintă şi oala cu toartă, întregită, descoperită într-o mică groapă din caseta nr. 2, deasupra locuinţei 1/2006. Prin formă şi dimensiuni ea este asemănătoare cu forma oalei cu toartă din cadrul ceramicii de uz nesmălţuită. În privinţa decorului adaptat se vede cum suprafaţa interioară a vasului a fost acoperită în întregime cu o peliculă subţire de smalţ de culoare cafeniu deschis. În exterior, pe marginea buzei a fost trasată o linie incizată, acoperită cu acelaşi smalţ ca în interiorul vasului. Pe peretele exterior al buzei a fost trasată cu vopsea maro o linie în val larg. Apoi pe umărul vasului sunt trasate, tot $\mathrm{cu}$ vopsea maro, două registre de linii în val încadrate între linii paralele, mai subţire sau mai gros trasate. Umărul vasului este decorat cu un registru de linii paralele, depărtate, în care au fost trasate linii oblice, distanţate. În fine sub acest registru a mai fost trasată o linie în val (planşa 7, fig. 4). Toarta vasului nu s-a găsit, dar se vede pe peretele vasului locul unde a fost lipită. Smalţul interior de culoare cafenie şi motivul decorativ pictat cu culoare maro sunt elemente specifice ceramicii otomane din secolul al XVIII-lea, de tip Ceanakkale (Aslanapa 2006).

Aşa cum am menţionat în rândurile de mai sus, pe suprafaţa podelei L.2/2007 a fost descoperit un inel din bronz, a cărui verigă face corp comun cu scaunul puţin înălţat şi lăţit. Decorul de pe suprafaţa lui nu se mai păstrează. Piese similare au mai fost descoperite în campaniile anterioare (Chiţescu et alii 1982). D.V. Rosetti susţine că aceste inele, descoperite în diferite situri din Ţara Românească erau folosite ca inele amulete în secolul al XVI-lea (Rosetti 1972).

Piesa din os are o formă conică cu înălţimea de $0,03 \mathrm{~m}$ şi diametrul gurii de 0,01 m. Această piesă probabil că era utilizată ca împungător şi s-ar putea să fi fost confecţionată într-unul din atelierele de prelucrare a osului, care a funcţionat în vatra oraşului.

Fragmentul de amuletă a fost confecţionat dintr-o placă de gresie mică, subţire, cu marginile rotunjite. Lângă muchia ruptă din vechime se află o gaură pentru agăţat. S-ar putea ca acestă piesă să fi fost folosită pentru realizarea decorului lustruit pe pereţii vasele ceramice. 
Mărgica din sticlă are o formă sferică decorată cu linii vălurite de culoare bleu, neagră şi alb murdar.

Anca Păunescu, Irina Ene

\section{Sector Grind nr. 2.}

În cadrul proiectului managerial referitor la valorificarea rezultatelor cercetărilor arheologice prin integrarea sitului într-un traseu turistic al judeţului Ialomiţa, s-a hotărât ridicarea unei construcţii, în care se va amenaja un micromuzeu de sit şi o bază arheologică a şantierului. Pentru amplasarea acestei construcţii, în campania din vara anului 2007 a fost delimitată o zonă din limita nord-estică a Grindului nr. 2 din aria sitului, în care, anterior, au avut loc multe intervenţii antropice. În această zonă stratigrafia grindului a fost distrusă cu ocazia lucrărilor de refacerea a şoselei DN 2A după inundaţiile din anul 1970. Limita nordică a grindului a fost decapată şi pământul a fost împins pentru înălţarea şoselei actuale.

Cercetarea arheologică cu caracter de sondaj, întreprinsă în acest loc s-a efectuat în vederea descărcării de sarcină arheologică a unei suprafeţe de $200 \mathrm{~m}^{2}$. În acest scop s-au trasat trei secţiuni, paralele, orientate nordsud, fiecare cu dimensiunile de $20 \times 2 \mathrm{~m}$, cu martori de $1 \mathrm{~m}$ şi $4 \mathrm{~m}$ între ele.

După îndepărtarea stratului de pământ vegetal, în suprafaţa secţiunilor A şi B, au apărut la adâncimea de $-0,35 \mathrm{~m}$ resturi ale unei podele din pământ granulat, bine bătut, de culoare negru-cenuşos şi gropi de pari care indică existenţa unei amenajări sezoniere. Pe aceste resturi de podea s-au aflat doar câteva fragmente mici de chirpic ars, urme de cenuşe şi pigment de cărbune. În capătul sudic al secţiunilor A şi B, la adâncimea de $-0,40 \mathrm{~m}$ a apărut un pământ galben lutos cu slabe urme de arsură. Inventarul arheologic recoltat este foarte sărac şi se compune din mici fragmente ceramice rulate, provenite de la vase de uz nesmălţuite şi foarte multe spărturi de oase de animale. Sub acest nivel de locuire, la adâncimea de $0,45 \mathrm{~m}-0,55 \mathrm{~m}$ a apărut stratul de pământ lutos, steril din punct de vedere arheologic.

Anca Păunescu

\section{Sector Grind nr. 3-Avicola ${ }^{4}$.}

În cursul campaniei din anul $2006 \mathrm{~s}-\mathrm{a}$ prelungit spre est $\mathrm{S} .1 / 2003$ cu $20 \times 2,5 \mathrm{~m}$. pentru a urmări dispunerea locuinţelor în această zonă. Tot acum a fost trasată şi caseta. B/2006, $(7,50 \times 6 \mathrm{~m})$ în prelungirea casetei A şi paralelă cu S.I/2003, păstrânduse un martor de $0,50 \mathrm{~m}$, cu scopul de a cerceta suprafaţa locuinţei nr. 7 (Păunescu et alii, 2006). În campania anterioară a fost surprinsă parţial Locuinţa nr. 4 în zona de nord-vest a casetei A. Pentru cercetarea ei integrală, s-a trasat caseta C. $(7 \times 4 \mathrm{~m})$, paralelă cu latura de nord a casetei A. S-a continuat şi cercetarea în Secţunea S III (zona necropolei nr. 3), întreruptă din cauza vremii nefavorabile din anul 2005 (planşa 8).

În încercarea de a dezveli integral Locuinţa nr. 4/2004, în suprafaţa casetei C, după înlăturarea stratului de pământ vegetal, la adâncimea de $-0,49 \mathrm{~m}$ a apărut un sfert din suprafaţa podelei din lut bătut (grosimea de $0,10 \mathrm{~m}$ ) a unei noi locuinţe, numerotată cu nr. 8, care suprapune Locuinţa nr. 4. În partea de vest a suprafeţei casetei $C$, a fost surprinsă la adâncimea de $-1 \mathrm{~m}$, bârna talpă (grosimea = $0,20 \mathrm{~m}$ ) a locuinţei Locuinţei nr. 4, cu orientarea nord-sud, care delimitează latura de est a locuinţei. În vecinătatea bârnei erau două gropi de pari $(\mathrm{d}=0,20 \mathrm{~m})$. Inventarul arheologic descoperit pe suprafaţa podelei $\mathrm{nr}$. 8 era alcătuit din fragmente ceramice mărunte, neîntregibile, ce aparţin categoriei ceramicii de uz nesmălţuită şi câteva fragmente de străchini smălţuite specifice secolului al XVII-lea.

În suprafaţa casetei $\mathrm{B} / 2006$, s-a completat planul Locuinţei nr. 7/2005 a cărei podea se afla la adâncimea de $-0,85 \mathrm{~m}$, prin dezvelirea laturii de est, lungă de $8 \mathrm{~m}$ şi a

\footnotetext{
${ }^{4}$ Sector al Muzeului Județean Ialomița — Slobozia.
} 
laturii de nord-sud, lungă de $6 \mathrm{~m}$, latura estică fiind delimitată prin amprenta bârnei locuinţei şi a gropilor de pari. Pe suprafaţa podelei, în colţul de sud-vest s-au găsit mai multe fragmente ceramice şi următoarele piese: un pahar tronconic, cu suprafaţa interioară acoperită cu smalţ de culoare verde, un un disc din pastă roşie decorat cu un brâu alveolat, concentric, dispus în zona mediană, un fragment de pahar cu picior tronconic înalt, un tripod, o gripcă din fier. Pe baza cotei de adâncime a podelei locuinţei şi a analogiilor pentru materialul ceramic (Ionaşcu, Zirra 1959), datarea acestui complex aparţine începutului secolului al XVI-lea.

În colţul sud-estic al casetei $B$, la adâncimea de $-0,60 \mathrm{~m}$ a fost surprins colţul de nord-vest a locuinței cercetate, în secţiunea LIX/1986 (Chiţescu et alii 1992). Pe planul general actual al dispunerii locuinţelor din acest sector, locuinţa cercetată în campania din 1986 a căpătat numărul 9.

În anul $2007 \mathrm{~s}$-a continuat cercetarea pe Secţiunea I/2006, prelungire spre est şi paralel cu latura nordică a ei s-a trasat S. III $(24 \times 2,50 \mathrm{~m})$ spre est, pentru a cerceta integral locuinţele nr. $10,11 \mathrm{a}$ şi $11 \mathrm{~b}$, interceptate în cursul campaniei din 2006.

Locuinţa nr. 10 surprinsă parţial în suprafaţa secţiunilor I/2003 şi III/2005 avea podeaua din lut la adâncimea de $0,90 \mathrm{~m}$. Suprafaţa podelei pe axul secţiunii, est-vest, măsoară $8 \mathrm{~m}$. Pe acestă suprafaţă s-au găsit prăbuşite bârne întregi şi fragmente de bârne carbonizate Pe una din bârne s-a păstrat şi o scoabă de legătură. Tot pe podea s-a găsit şi urma unei vetre de formă rotundă $(d=1,50$ m) situată pe latura nordică, cu pereţii construiţi din lut galben, având o grosime de $0,25 \mathrm{~m}$. Suprafaţa vetrei, datorită folosirii îndelungate s-a pietrificat. În partea sudică a vetrei a fost surprinsă groapa de alimentare şi un cenuşar cu diametrul de $1 \mathrm{~m}$, adâncită în podeaua de lut. Inventarul arheologic recoltat de pe suprafaţa podelei se compune din fragmente de ceramică nesmălţuită, o greutate din piatră pentru plasa de pescuit şi câteva fragmente mărunte de ceramică otomană provenită din atelierele de la Iznik. Din punct de vedere al stratigrafiei şi al materialelor recoltate L. 10 a fost contemporană cu L. 2 şi L. 7, la începutul secolului al XVI-lea (planşa 9).

Podeaua din lut a locuinţei nr. 11a a fost surprinsă în secţiunile I şi III, la adâncimea $-0,30 \mathrm{~m}$. Laturile lungi $(6 \mathrm{~m})$ aveau orientarea est-vest, iar laturile scurte (5 m) erau orientate nord-sud. În colţul nordestic s-a găsit vatra sobei cu diametrul de $0,40 \mathrm{~m}$, iar în jurul ei fragmente de oale cahle. Inventarul arheologic mai conţinea un inel din bronz cu o piatră de culoare verde (planşa 10, fig. 1) fragmente de străchini smălţuite cu picior inelar, fragmente de căni, din pastă roşie cu gura lobată, fragmente de pipe din lut. Tot în acelaşi perimetru, la adâncimea de $-0,50 \mathrm{~m} \mathrm{~s}$-a delimitat podeaua locuinţei $11 \mathrm{~b}$, având aproximativ aceleaşi dimensiuni cu locuinţa 11a. Menţionăm în afară de fragmentele de ceramică de uz nesmălţuită şi smălţuită, fragmentele de cahle din pastă ceramică nesmălţuită, decorate cu motive geometrice (planşa 10, fig. 2, 3, 5, 6).

Stratigrafia nivelelor de locuire cercetate până în prezent ne îndreptăţeşte să afirmăm existenţa a patru nivele de locuire. Distribuţia şi cazurile de suprapunere ale unor locuinţe sugerează dreptul de proprietate asupra unei suprafețe de teren, iar planul lor, păstrează aceeaşi orientare, determinată de factorii climatici, care indică un aliniament faţă de o cale de acces (planşa 11, fig. 1-4).

În suprafaţa secţiunii IV/2007, trasată pentru cercetarea în continuare a necropolei nr. 3, la adâncimea de $-0,62 \mathrm{~m}$, a fost descoperită parţial podeaua unei locuinţe pe care erau aşezate grupuri de cărămizi, ca un paviment (planşa 8).

O altă categorie de complexe sunt gropile pentru depozitarea reziduurilor menajere.

Groapa nr. 2 s-a aflat la adâncimea de $-0,88 \mathrm{~m}$, în casetele A şi C. Conturul ei prezenta o formă pătrată $(1,50 \times 1,50 \mathrm{~m})$ şi 
pereţi drepţi ai ei coboară până la adâncimea de $1,10 \mathrm{~m}$. Pe fundul gropii s-a găsit o amenajare din bârne de lemn, aşezate pe direcţia nord-sud. Presupunem ca acest complex a fost utilizat ca groapă de provizii. În umplutura gropii s-au găsit puţine fragmente ceramice. Presupunem ca această groapă este contemporană cu L. nr. 2, datată la începutul secolului al XVI-lea.

Groapa nr. 3 s-a aflat în caseta C, la adâncimea de $0,50 \mathrm{~m}$, cu conturul rotund $(\mathrm{d}=$ $0,60 \mathrm{~m}$ ), coboară până la adâncimea de 1,61 $\mathrm{m}$.

Pe fundul gropii s-a găsit o bârnă groasă de lemn, carbonizată. Două treimi din umplutura gropii era formată din bulgări de chirpic ars, pe care se păstra amprenta bârnelor și a nuielelor împletite din structura pereţilor unei locuinţe. Deasupra chirpicului au fost găsite spărturi de oase de bovine. Pe baza stratigrafiei şi a relaţiei cu locuinţa nr. 8 , acest complex se poate data la sfârşitul secolului al XVI-lea.

Groapa nr. 4 din S. I /2006 a apărut la adâncimea de $0,80 \mathrm{~m}$ faţă de nivelul actual de călcare, la vest de Locuința nr. 10. Conturul gropii era rotund cu diametrul de $3 \mathrm{~m}$. Pereţii drepţi ai gropii coborau până la adâncimea de $-1,75 \mathrm{~m}$. În umplutura gropii au fost descoperite fragmente ceramice provenite de la vase de uz nesmălţuite şi vase smălţuite (planşa 10, fig. 8). Între fragmentele de cahle ornamentale menţionăm un fragment de cahlă nesmălţuită, cu decor traforat (planşa 10 , fig. $4,9,18$ ), asemănătoare cu cea descoperită în inventarul unei locuinţe de pe Grindul nr. 1 (Chiţescu et alii 1979), un fragment de cahlă cu imaginea Sfântului Gheorghe, fragmente de cahle smălţuite, decorate cu motive geometrice. Altă categorie de obiecte o constituie uneltele din os-străpungătoare. Pe baza inventarului, acest complex se datează la jumătatea secolului al XVI-lea.

Necropola nr. 3 se află în capătul vestic al secţiunilor $1,3,4$. În campania din anul 2006 s-au cercetat 8 morminte de inhumaţie (M. 80-87), din care trei aparţin unor subiecţi infans 1 - M.80, infans II M.81 şi M.86 şi restul adulţi. Scheletele au fost aşezate în decubit dorsal, cu orientarea vest-est, cu membrele superioare aduse pe piept sau pe bazin, excepţie făcând M.85, care avea ambele braţe îndoite din cot şi palmele aduse pe pe umăr. Singurul caz de suprapunere, întâlnit în această campanie este M.83 care suprapune parţial pe M.84. Numai în M.82 a fost găsit ca inventar, un inel de argint, cu veriga răsucită şi placa rotundă, decorată cu o cruce în relief.

Gheorghe Matei, Gabriel Vasile

\section{Sector Grind nr. 6.}

În vederea protejării şi a punerii în valoare a monumentelor descoperite în vatra abandonată a Oraşului de Floci, în vara anului 2007 s-au făcut lucrări de conservare primară şi protejare a zidurilor de fundaţie şi a fragmentului din peretele nordic al Bisericii nr. 1. Întregul complex a fost înconjurat cu un gard pentru a fi ferit de acţiunile antropice. Menţionăm descoperirea unui inel sigilar din argint şi a unui ac de maramă, podoabe specifice secolului al XVI-lea, descoperite passim în apropierea fragmentului de zid.

Gheorghe Matei

\section{Sector Grind nr. 8.}

Grindul nr. 8 este situat în extremitatea sud-vestică a sitului arheologic de la Oraşul de Floci. Până în prezent această zonă din cadrul sitului nu a fost cercetată arheologic. Grindul este situat la o distanţă de aproximativ $400 \mathrm{~m}$ spre vest faţă de grindul nr. 6 (pe care se află ruinele bisericii nr. 1) considerat - datorită vestigiilor importante cercetate aici de-a lungul timpului — un punct central din vatra fostului oraş medieval. În stadiul actual al cunoştinţelor asupra sitului, această zonă este apreciată ca fiind una periferică, având $\mathrm{o}$ importanţă economico-socială oarecum secundară în raport cu nucleul urban propriu-zis, însă doar 
rezultatele investigaţiilor sistematice vor putea oferi o imagine reală a potenţialului arheologic al acestui perimetru. În acest context se cuvine menţionat şi faptul că până în 1990 întregul sit arheologic a fost intens utilizat ca şi teren agricol, ceea ce a determinat importante transformări al morfologiei grindurilor şi implicit al stratigrafiei zonei.

\section{Date preliminare}

În luna iunie 2007, pe grindul 8 de la Oraşul de Floci au fost realizate, de către specialişti de la Facultatea de Geologie şi Geofizică a Universităţii din Bucureşti, prospecţiuni geomagnetice pentru depistarea unor eventuale zone cu potenţial arheologic. Investigaţiile au constat în determinări ale anomaliei câmpului gravitaţional efectuate într-o rețea regulată cu pasul de $1 \mathrm{~m}$. Rezultatele astfel obţinute au fost analizate prin interpolarea datelor cu metode specifice datelor din clasa câmpuri potenţiale, conturându-se astfel zonele de potenţial interes pentru cercetarea arheologică de detaliu. La interpretarea datelor s-a ţinut cont de specificul construcțiilor de la Oraşul de Floci (cel mai frecvent acestea fiind constituite din chirpic parţial ars) şi de tipul materialelor rezultate în urma activităţilor meşteşugăreşti specifice perioadei în care s-a dezvoltat habitatul urban.

După executarea mai multor transecte pe care nu au fost semnalate anomalii semnificative ale câmpului magnetic, a fost identificată pentru cartarea de detaliu o zonă de cca. $40 \times 20 \mathrm{~m}$. În zona în care a fost realizată prospectarea micro-magnetică a fost observat un areal concretizat în informaţia geofizică printr-un dipol clar conturat care poate fi generat de o clădire din cărămidă arsă sau o zonă de depozitare a unor deșeuri ale activităţii artizanale.

Acest areal a fost desemnat pentru o cercetare arheologică de detaliu. Alte zone, care ar putea prezenta un interes secundar, sunt situate la sud de cea menţionată şi pot fi reperate prin trasarea a două secţiuni de sondaj de mici dimensiuni.

\section{Cercetarea arheologică}

Campania anului 2007 în zona grindului 8 a avut drept obiectiv verificarea în teren a indiciilor furnizate de prospecţiunile magnetometrice, respectiv deschiderea unor unităţi de cercetare în zona evidenţiată cu potenţial arheologic. Pe această suprafaţă, de cca. $200 \mathrm{~m}^{2}$, au fost trasate şase secţiuni, respectiv $\mathrm{S} 001(20 \times 2 \mathrm{~m}), \mathrm{S} 002(20 \times 2 \mathrm{~m})$, S $003(20 \times 2 \mathrm{~m}), \mathrm{S} 004(8 \times 2 \mathrm{~m}) \mathrm{S} 005(10$ $\times 2 \mathrm{~m})$ şi S $006(8 \times 2 \mathrm{~m})$, toate orientate sudnord. S 001, S 002, S 003, S 004 şi S 006 au fost situate paralel, una de cealaltă, doar $S$ 005 fiind deschisă în prelungirea lui S 001, spre sud. Între S 001 S 002 şi S 003 martorul are o lăţime de $1 \mathrm{~m}$. Între S 002, S 004 şi S 006 martorul este de $0,5 \mathrm{~m}$ (planşa 12).

$\mathrm{Au}$ fost investigate şi parţial cercetate 27 de complexe dintre care nouă morminte de inhumaţie, o amenajare sezonieră, celelalte fiind gropi pentru depunerea reziduurilor menajere.

Stratigrafia generală a perimetrului investigat.

Stratigrafia celor trei secţiuni paralele (S 001, S 002, S 003) este una relativ unitară. Descrierea nivelurilor arheologice este făcută de la nivelul actual de călcare (planşa 13).

Nivelul 1. $0-0,30 / 0,32 \mathrm{~m}$. Nivel de pământ de culoare brun cenuşiu, prăfos, cu pigmente de cărbune şi material arheologic amestecat, foarte afânat, cu o textură preponderent argiloasă, reprezentând orizontul organic al solului actual. Foarte afectat de lucrările agricole efectuate în zonă (arătură).

Nivelul 2. $-0,32 / 0,67 \mathrm{~m}$. Nivel de pământ culoare brun măzăros constituit dintro depunere antropică de material arheologic variat: fragmente ceramice nesmălţuite şi smălţuite (vase de uz comun, dar şi fragmente de cahle), ceramică încadrată cronologic culturii „Dridu”, ceramică otomană de Iznik, oase de animale, nasturi şi plăsele din os, 
reprezentând un strat de depunere în vederea înălţării solului.

Nivelul 3. $-0,67 \mathrm{~m}-0,75 / 0,89 \mathrm{~m}$. Nivel de lut culoare galbenă, fără material arheologic, reprezentând un strat de nivelare.

Nivelul 4. $-0,75 / 0,89 \mathrm{~m}-1,12 / 1,14 \mathrm{~m}$. Nivel de pământ de culoare brun măzăros, constituit dintr-o depunere antropică de material arheologic variat: fragmente ceramice nesmălțuite şi smălţuite (vase de uz comun dar şi fragmente de cahle), ceramică încadrată cronologic culturii „Dridu”, ceramică otomană de Iznik, oase de animale, nasturi şi plăsele din os, reprezentând un strat de depunere în vederea înălţării solului.

Nivelul 5. $-1,12 / 1,14 \mathrm{~m}-1,34 \mathrm{~m}$. Nivel de lut de culoare galbenă, fără material arheologic, reprezentând un strat de nivelare.

Nivelul 6. $-1,34 \mathrm{~m}-1,59 / 1,72 \mathrm{~m}$. Nivel de lut compact de culoare verzuie, aluvionar, fără material arheologic.

Nivelul 7. $-1,72 \mathrm{~m}$. Sterilul arheologic. investigate

Distribuţia topografică a complexelor

Mormintele sunt situate în jumătatea nordică a secţiunilor S 001, S 002 şi S 003 , ceea ce ne-a permis - cel mai probabil — să identificăm limita sudică a necropolei de pe acest grind (desemnată cu numărul şapte în ordinea descoperirii lor pe situl arheologic de la Oraşul de Floci).

În partea de sud a acestor secţiuni, dar şi în S 005 au fost identificate complexele având funcţionalitatea de gropi pentru depunerea reziduurilor menajere, iar amenajarea sezonieră - în care am surprins o podea - a fost cercetată în S 002, S 003, S 004 şi S 006, carourile 4 şi 6.

\section{Descrierea complexelor}

Mormintele de inhumaţie, sunt orientate est-vest şi depuse în decubit dorsal, gropile lor fiind amenajate în stratul de lut constituit ca o nivelare (3) în extremitatea nordică a secţiunilor S 001 , S 002 şi S 003 (planşa 14, fig. 1-2).
M1 (cpl. 1). Localizare: S 001, caroul 10; groapă de formă dreptunghiulară; $\mathrm{L}^{5}=$ $1,52 \mathrm{~m}, 1=0,75 \mathrm{~m}$; ad.s. $=0,30 \mathrm{~m}$; ad.c.s. $=$ $0,72 \mathrm{~m}$; ad.f.gr. $=0,96 \mathrm{~m} . \mathrm{Nu}$ au fost observate indicii privind existenţa marcajelor exterioare.

Din umplutura gropii provin fragmente ceramice de mici dimensiuni, (ceramică de tip „Dridu” şi ceramică nesmălţuită şi smălţuită preponderentă) şi oase de animale, reprezentând material arheologic rulat.

Scheletul, depus în sicriu de lemn cu capac, este orientat est-vest. Craniul este cu bărbia în piept iar antebraţul stâng este poziţionat peste cel drept în zona osului stern. Coloana este uşor deplasată în zona vertebrelor 4 şi 5 . Membrele inferioare sunt paralele şi întinse.

Inventar: două monede, una aflată sub antebraţul stâng şi cealaltă căzută între vertebre. Prima monedă este un fals după un gros polonez de la Sigismund III (15871632), iar cea de a doua este un aspru otoman perforat, din secolele XVI-XVII, cu emitent neprecizat.

M2 (cpl. 5). Localizare: S 002, caroul 9-10; groapă de formă dreptunghiulară: $\mathrm{L}=$ $1,10 \mathrm{~m} ; 1=0,50 \mathrm{~m}$; ad.s. $=0,50 \mathrm{~m}$; ad.f.gr. $=$ $0,60 \mathrm{~m}$. $\mathrm{Nu}$ avem indicii despre existenţa marcajelor exterioare.

Din umplutura gropii provin fragmente ceramice de mici dimensiuni (ceramică de tip „Dridu”, preponderent ceramică nesmălţuită şi smălţuită şi ceramică de Iznik) şi oase de animale, reprezentând material arheologic rulat.

Scheletul este orientat est-vest, craniul cu bărbia în piept, uşor deranjat în zona coastelor, ulterior înmormântării, probabil din cauza lucrărilor agricole ceea ce a făcut să existe o presiune asupra scheletului de copil (lungimea acestuia la nivelul inferior al gropii este de $0,83 \mathrm{~m}$ ). Antebraţul drept se afla pe piept, iar cel stâng era căzut pe abdomen.

\footnotetext{
${ }^{5} \mathrm{~L}$ = lungimea; 1 = lăţimea; ad.s. = adâncimea surprinsă; ad.c.s. = adâncimea la nivelul capacului de la sicriu; ad.f.gr. = adâncimea la fundul gropii mormântului.
} 
Inventar: o monedă, respectiv un aspru otoman de secol XVI-XVII, al cărei emitent nu poate fi precizat

M3 (cpl. 10, S 003, caroul 9) M4 (cpl. 11, S 001, caroul 9) M5 (cpl. 12, S 003, caroul 10) M6 (cpl. 13, S 003, caroul 9) M7 (cpl. 14, S 003, caroul 7-8) M8 (cpl. 16, S 001, caroul 10) M9 (cpl. 18, S 003, caroul 9) au fost identificate şi parţial cercetate, campania următoare propunându-şi investigarea lor exhaustivă.

Amenajarea sezonieră suprapune din punct de vedere stratigrafic, nivelul $3^{6}$ complexul fiind vizibil imediat la baza nivelului 1 şi constă dintr-o podea de lut, cu urme de arsură în zona nord-estică. $\mathrm{Nu}$ au fost identificate alte detalii constitutive ale elevaţiei complexului (şanţuri de implantare a pereţilor de lemn), cu excepţia unei gropi în colţul de sud vest care provenea probabil de la un pilon de susţinere a acoperişului. În extremitatea de nord est a complexului (partea în care au fost identificate urmele de arsură concretizate într-o porţiune în care lutul prezintă o crustă roşiatică). Inventarul arheologic recoltat din această porţiune (trei mici fragmente ceramice atipice şi un fragment de cărămidă), cât şi amplasamentul ei în economia spaţială a întregului complex, ne-a determinat să presupunem că este vorba de o vatră care a funcţionat un timp scurt.

Inventarul complexului: mici fragmente ceramice (fund drept de la o oală borcan) cărămidă spartă, oase de peşte, câteva oase prelucrate sub forma unor nasturi şi bucăţi de lemn ars, dar şi un mic depozit monetar, alcătuit din monede de argint lipite, cea mai recentă piesă lizibilă fiind de la Sigismund III Vasa (1587-1632) (planşa 15, fig. 2).

Cele mai târzii fragmente ceramice şi monedele din inventarul acestui complex arheologic, datate între sfârşitul secolului al XVI-lea şi începutul secolului al XVII-lea, stabilesc perioada de sa funcţionare în acest

\footnotetext{
${ }^{6}$ Vezi supra stratigrafia perimetrului.
}

interval de timp. Cercetarea acestui complex nu este încheiată, campania viitoare propunându-şi continuarea investigaţiilor arheologice asupra zonei reperate pentru a putea clarifica situaţia din teren.

\section{Gropile de reziduuri menajere}

Gropile cu depunere de reziduuri sunt gropi de formă cilindrică, cu un diametru cuprins între $1 \mathrm{~m}$ şi $1,5 \mathrm{~m}$ şi o adâncime de maxim $1 \mathrm{~m}$ (mai puţin groapa nr. 8/cpl. 17).

Cele trei gropi din S 001, respectiv Gr. nr. 1/cpl. 2; Gr. nr.2/cpl. 3, şi Gr. nr. 3/cpl. 4, par să fie amenajate din nivelul $2^{7}$ (planşa 13 , fig. 3).

În general, inventarul arheologic al acestor complexe este foarte sărac. Menţionăm însă, din inventarul gr. $\mathrm{nr} .1 / \mathrm{cpl}$. 2 , un fund inelar de strachină pictat cu vopsea albă în interior, fragmente de perete de la oale borcan, o bucată de chirpic, patru fragmente de la obiecte de fier, oase de peşte şi o monedă (un aspru otoman de secol XVI pe care nu se mai poate citi emitentul). Materialul ceramic se încadrează cronologic, de asemenea, în secolul al XVI-lea. În Gr. nr. 2/cpl. 3 a fost descoperită o plăsea de os decorată cu incizii sub formă de cercuri şi pictată roşu şi verde, iar în Gr. nr. 3/cpl. 4 un degetar de bronz (planşa 15, fig. 9).

O situaţie aparte o reprezintă Gr. nr. 8/cpl. 17, surprinsă în S 001, carourile 6-8. Iniţial au fost două gropi, a şi b, după cum se poate vedea în profil (straturile arheologice din întreaga secţiune se reiau pe o lungime de $0,25 \mathrm{~m}$ ) care s-au unificat în timpul depunerii de pământ cu material arheologic, care constituie stratul II. Aceasta are un diametru pe profilul de vest de $3,5 \mathrm{~m}$, iar adâncimea ei atinge sterilul arheologic la $-1,72 \mathrm{~m}$.

Gropile nr.10 (cpl. 20), 12 (cpl. 22), 13 (cpl. 23), 14 (cpl. 24), 15 (cpl. 25), 17 (cpl. 27) au fost surprinse în $\mathrm{S} 005$ şi pornesc din stratul de nivelare cu lut galben (3). Diametrul lor este cuprins între $1 \mathrm{~m}$ şi $1,50 \mathrm{~m}$ (planşa 13, fig. 2).

\footnotetext{
${ }^{7}$ Vezi supra stratigrafia perimetrului.
} 
În aceste complexe au fost descoperite puţine materiale arheologice, din care menţionăm în Gr. nr. 12/cpl. 22 un fragment ceramic de Iznik decorat cu alb albastru şi negru, precum şi două fragmente ceramice atipice, iar în Gr. nr. 13/cpl. 23 două fragmente ceramice din care un fund de oală borcan, tip ceramic întâlnit pe o lungă perioadă de timp. Inventarul Gr. nr. 14/cpl. 24 se compune din patru fragmente ceramice atipice provenite probabil, de la vase de uz comun smălţuite şi nesmălţuite, iar cel al Gr. nr. $15 / \mathrm{cpl}$. 25 dintr-un os prelucrat sub forma unui nasture.

Tot în S 005 au fost cercetate Gropile nr. 11/cpl. 21 şi nr. 16/cpl. 26 care pornesc, însă, din stratul 2, de pământ cu materiale arheologice variate, adus şi depus.

Acelaşi tip de complex a fost cercetat şi în S 002 (Gr. nr. 4/cpl. 6, Gr. nr. 5/cpl. 8 şi Gr. nr. 7/cpl. 15) şi S 003 (Gr. nr. 6/cpl. 9 şi Gr. nr. 9/cpl. 19) şi prezintă aceleaşi caracteristici prezentate anterior.

Întrucât materialul arheologic rezultat din cercetarea acestor complexe este redus numeric, variat şi fragmentar, coroborat şi cu dimensiunile reduse ale fragmentelor, trebuie să presupunem că acestea vor fi funcţionat iniţial ca şi gropi de păstrare a alimentelor, caz atestat la Oraşul de Floci. În această situaţie considerăm că umplerea lor s-a făcut prin aducerea pământului $\mathrm{cu}$ material arheologic care formează nivelul 2.

\section{Materialul arheologic}

În afara inventarelor complexelor prezentate, de pe întreaga suprafaţă investigată în această campanie a fost recoltat un bogat şi variat material ceramic fragmentat ${ }^{8}$, oase de animale, obiecte din os, oase de peşte, fragmente din obiecte de fier, bucăţi de zgură, piatră şi cărămidă.

În prezentarea materialului ceramic începem cu menţionarea a patru fragmente ceramice tip Dridu, atipice, descoperite la

\footnotetext{
8 Restaurarea şi desenul pieselor ceramice au fost realizate în cadrul laboratoarelor şi secţiilor specializate ale MNIR
}

cote diferite şi în secţiuni diferite (planşa 15, fig. 7-8).

Fragmentele ceramice de uz comun, nesmălţuite provin de la următoarele forme: oale borcan, farfurii, sfeşnice, vase de mici dimensiuni şi oale cahlă. Oalele borcan au buza evazată şi marginea teşită orizontal, cu striuri pe suprafaţa exterioară (planşa 15, fig. 1). Farfuriile sunt realizate din pastă arsă oxidant şi acoperite cu o angobă fină de culoare roşiatică, pictate cu pastă albă. Au fost găsite, de asemenea, trei fragmente din partea superioară a unor ulcioare, precum şi buza de la un vas trilobat (planşa 15, fig. 2). Piciorul sfeşnicelor nesmălţuite este decorat cu alveole, prin simpla apăsare cu degetul în pasta moale. Vasele de mici dimensiuni, din pastă foarte fină, arsă cărămiziu, au buza trasă uşor spre exterior şi o şănţuire largă pe suprafaţa ei, fragmentele descoperite fiind decorate cu două striuri incizate imediat sub marginea buzei şi pictate cu pete de culoare galbenă.

Ceramica smălţuită este reprezentată prin fragmente provenite de la următoarle forme: străchini, farfurii şi vase cilindrice. Străchinile sunt de diferite dimensiuni, au fundul inelar sau drept profilat, suprafaţa fiind acoperită cu smalţ monocrom sau policrom. De asemenea, unele vase au decor sgrafittat, pe un fond verde sau galben fiind realizat un decor geometric, floral sau sub forma unor solzi de peşte. Fragmentele de farfurii smălţuite au pereţii evazaţi şi muchia teşită oblic sau au marginea alveolată. Decorul este în cea mai mare parte sgrafittat, predominând culoarea verde (planşa 15, fig. 3-6). Vasele cilindrice au pereţii groşi şi suprafaţa interioară are un smalţ — în special — de culoare maronie.

Ceramica de import (Iznik) este reprezentată de câteva fragmente neîntregibile, descoperite în contexte arheologice diferite, nefiind posibilă o încadrare tipologică a acestora, ci doar o prezentare a culorilor, respectiv alb, albastru, verde şi roşu (planşa 16, fig. 1-3). 
Ceramica decorativă smălţuită şi nesmălţuită este de asemenea, fragmentară şi neîntregibilă. Între tipurile identificate menţionăm un fragment de la o placă cu reprezentarea Sfântului Gheorghe, dar şi din cele decorate cu cercuri, cu motive florale sau geometrice şi un fragment traforat, specifice secolului al XVI-lea (planşa 16, fig. 4-8).

De asemenea, au fost descoperite trei fragmente de pipe de culoare roșiatică, fără decor, cu excepţia uneia care are perforate trei orificii şi o cute de gresie. Piesele descoperite passim sunt fragmente ceramice smălţuite şi nesmălţuite, asemănătoare celor prezentate anterior, o greutate pentru plasa de pescuit cu şanţ pentru şnur şi cu o perforaţie marginală şi un fragment de pipă de culoare albă cu un decor incizat format din linii paralele.

Materialul ceramic este rulat și compus din fragmente neîntregibile, formele identificate şi pasta lor indicând o încadrare cronologică vastă, din a doua jumătate a secolului al XVI-lea şi până către sfârşitul secolului al XVII-lea.

Materialul recoltat din nivelul 2 din $S$ 001 se compune din 11 oase prelucrate sub forma unor nasturi şi plăsele, asemănătoare celor descoperite în atelierele de prelucrare a osului (Chiţescu et alii, 1981), ceea ce ne-a determinat să luăm în considerare posibila existenţă în zonă a unui atelier de prelucrat osul în zonă, ipoteză neconfirmată încă în acest stadiu al cercetării. Acest tip de obiect este prezent şi în celelalte secţiuni, dar cu o pondere mult mai mică.

Fragmentele provenite de la diverse obiecte de fier şi zgură sunt predominante în nivelul 2, cu toate că, în acest stadiu al cercetării nu a fost reperat în zonă un atelier de acest fel.

Oasele de peşte sunt întâlnite în special în umplutura gropilor, dar şi pe suprafaţa podelei sezoniere - cpl.7.

Menţionăm şi două fragmente de sticlă descoperite în S 003, din care unul provine probabil de la piciorul unui pahar.
Dintre monedele descoperite ${ }^{9}$, puţine pot fi considerate utile pentru datare, întrucât majoritatea sunt falsuri sau au fost refolosite ca podoabe (paietă, M.1/cpl. 1). Asprii otomani din inventarul mormintelor (M.1/cpl. 1 şi M.2/cpl. 5) sunt ieşiţi din circulaţie şi utilizarea lor este mai târzie, putând fi stabilit doar un termen post quem. În ceea ce priveşte dinarul unguresc de la Matei Corvin (14581490) (planşa 14, fig. 3) descoperit în S 001, caroul 6 , la $-0,60 \mathrm{~m}$, acesta este foarte ars, iar argintul s-a păstrat foarte puţin.

\section{Concluzii}

Stratigrafia descrisă anterior, confirmă, în mare măsură, rezultatele prospecţiunilor, fiind prezente depunerile masive de reziduuri, în special material ceramic, dar şi oase de animale, depuse în două etape, respectiv nivelele 2 şi 4 . Acest grind nu a avut o cotă ridicată dar, după cum am observat stratigrafic, el a fost practic înălţat prin intervenţie antropică (nivelări succesive de pământ afânat cu material arheologic şi lut galben nisipos). Această situaţie poate fi interpretată din perspectiva unei singure activităţi constructive (cea de amenajare a grindului) cu cel puţin două momente. Astfel, întrucât materialul arheologic rezultat în urma cercetării arheologice nu poate fi încadrat cronologic unei anume perioade, la aceeaşi cotă şi în acelaşi carou regăsindu-se ceramică ce poate fi integrată culturii „Dridu”, fragmente de Iznik şi ceramică de uz comun nesmălţuită şi smălţuită, putem presupune formarea antropică a grindului în două etape, în ultima fiind identificate complexe arheologice care atestă o locuire în zonă, probabil la sfârşitul secolului al XVI-lea şi începutul secolului următor. De asemenea, extinderea necropolei nr. 7 în această zonă poate fi legată, cu prudenţa specifică unui astfel de demers, tocmai de perioada în care aceste lucrări de amenajare au făcut posibilă

\footnotetext{
${ }^{9}$ Monedele au fost prelucrate de către dl. Mihai Dima de la Muzeul Băncii Naţionale a României, căruia îi mulţumim şi pe această cale.
} 
extensia suprafeţei locuibile din situl medieval.

Continuarea cercetărilor în campaniile viitoare, extinse pe întreaga suprafaţă a grindului, vor aduce informaţii suplimentare care să contribuie la conturarea unei imagini de ansamblu în ceea ce priveşte locuirea pe acest grind, modalitatea în care s-a desfăşurat aceasta (sezonier sau permanent), precum şi precizarea limitelor necropolei nr. 7 de la Oraşul de Floci.

\section{Irina Ene, Dana Mihai}

\section{Sector Grind nr. 9.}

În vederea verificării datelor furnizate de prospecţiunile arheogeofizice în anii 2004-2005 (Păunescu et alii 2006) cercetarea $\mathrm{s}$-a continuat prin trasarea unei noi secţiuni, $\mathrm{S}$ $003(15 \times 1,5 \mathrm{~m})$ orientată nord-sud. În primele două secţiuni din campaniile anterioare au fost descoperite şi 6 morminte cu gropile adâncite în stratul de pământ steril arheologic. Pentru a verifica extinderea acestei necropole nr. 6 spre centrul grindului,
Secţiunea 003/2006 a fost trasată la o distanţă de $18 \mathrm{~m}$ spre vest de Secţiunea 002/2005.

Situaţia stratigrafică arată că după îndepărtarea stratului de pământ vegetal, cu o grosime de $0,25 \mathrm{~m}$, pe întreaga suprafaţă a secţiunii urmează un strat de pământ negrucenuşos, cu aspect grăunţos, în care s-au descoperit fragmente ceramice mici, rulate, oase sparte de animale, rare fragmente de chirpic şi câteva obiecte de uz din metal cum ar fi cuie, un piron, fragmente de balamale şi un cârlig pentru undiţă. Grosimea acestui strat variază între $0,50 \mathrm{~m}$ la capetele secţiunii şi $1 \mathrm{~m}$ în zona de centru. Sub acest strat se află un pământ lutos, de culoare galben închis, steril din punct de vedere arheologic. $\mathrm{Nu}$ au mai fost descoperite alte morminte, ceea ce presupune că necropola nr. 6 se continua spre limita estică a grindului.

Întrucât materialul arheologic recoltat este foarte puţin relevant pentru estimarea locuirii pe acest grind, pentru moment, cercetarea a fost întreruptă pe acest grind.

Dana Mihai, Anca Păunescu

\section{BIBLIOGRAFIE}

Aslanapa 2006 - O. Aslanapa, Turkish tile and ceramic art, Istanbul, 2006, p. 81-82 şi 94

Cantea 1959 - Gh. Cantea, Cercetări arheologice pe dealul Mihai vodă şi împrejurimi, în vol. Bucureştii de odinioară în lumina săpăturilor arheologice, Bucureşti, 1959, p. 104, pl. LXXXV/1-3.

Chițescu et alii 1979 - L. Chiţ̧escu, N. Conovici, R. Lungu, A. Păunescu, V. Rădulescu, Cercetări arheologice la Piua Petrii (Oraşul de Floci), jud. Ialomiţa, în Cercetări Arheologice, III, Bucureşti, 1979, p. 222 şi 234 , fig 19

Chițescu et alii 1981 - L. Chițescu, R. Lungu, T. Papasima, P. Vlădilă, V. Rădulescu și A. Păunescu, Cercetări arheologice în anul 1979 la Piua Petrii (Oraşul de Floci), comuna Giurgeni, jud. Ialomiţa, în Cercetări Arheologice, IV, București, 1981, p. 135-137, fig10/2.

Chițescu et alii 1982 - L. Chiţescu, T. Papasima, P. Vlădilă, V. Rădulescu, A. Păunescu, Cercetările arheologice de la Piua Petrii (Oraşul de Floci), jud. Ialomiţa, în Cercetări Arheologice, V, Bucureşti, 1982, p. 143, 145, fig. 9/6, 10/6, 9.

Chițescu et alii 1992 - L. Chiţescu, A. Păunescu, E. Rența, Gh. Matei, V. Şt. Niţulescu, Cercetările arheologice de la Piua Petrii (Oraşul de Floci), com. Giurgeni, jud. Ialomiţa, în Cercetări Arheologice, IX, Iaşi-Rădăuţi, 1992, p. 98.

Ionaşcu, Zirra 1959 - I. Ionaşcu, V. Zirra, Mănăstirea Radu Vodă şi biserica Bucur, în vol. Bucureştii de odinioară în lumina săpăturilor arheologice, Bucureşti, 1959, p. 76, pl. LVII.

Păunescu 1998-2000 - A. Păunescu, Cuptoare medievale de ars ceramica descoperite la Oraşul de Floci, judeţul Ialomiţa, în Cercetări Arheologice, XI, partea I-a, Bucureşti, 1998-2000, p. 182. 
Păunescu et alii 2006 - A. Păunescu, D. Mihai, S. Oţa, Gh. Matei, Cercetări arheologice în vatra Oraşului de Floci (Piua Petri), comuna Giurgeni, judeţul Ialomiţa, în Cercetări Arheologice, XIII, Bucureşti, 2006, p. 113-114, 121 şi fig. 10, p. 123, fig.24.

Rosetti 1959 - D. V. Rosetti, Curtea Veche, în vol. Bucureştii de odinioară în lumina săpăturilor arheologice, Bucureşti, 1959, p. 160, pl. CX.

Rosetti 1972 - D. V. Rosetti, Tezaurul de podoabe medievale de la Olteni (Teleorman) şi elementele lor bizantine, în Buletinul Monumentelor istorice, an XLI, nr. 4/1972, p. 6, 13. fig. 25.

Rosetti 1972 - D. V. Rosetti, Vestigiile feudale de la Suslăneşti (Jud. Argeş), în Buletinul Monumentelor Istorice, an XLI, nr. 2/1972, p. 34, fig. 6/9. Vezi notele 53 şi 54.

\section{LEGENDA FIGURILOR}

Planşa 1. Oraşul de Floci, planul general al grindurilor.

Planşa 2. Oraşul de Floci. Grindul nr. 1, planul casetelor.

Planşa 3. Oraşul de Floci, grind nr. 1, planul complexului nr. 2 - locuinţa 1/2006.

Planşa 4. Oraşul de Floci, grind nr. 1, planul complexului nr. 6, cuptor.

Planşa 5. Oraşul de Floci, grind nr. 1, planul complexului nr. 1, locuinţa nr. 1/2007.

Planşa 6. Oraşul de Floci, grind nr. 1, ceramică nesmălţuită, secolul al XVI-lea.

Planşa 7. Oraşul de Floci, grind nr. 1, ceramică smălţuită.

Planşa 8. Oraşul de Floci, grind nr. 3.

Planşa 9. Oraşul de Floci. Grind nr. 3, planul grund al locuinţei nr. 10/2007.

Planşa 10. Oraşul de Floci, grind 3, ceramică decorativă şi obiecte de uz descoperite în locuinţe şi gropi pentru depozitarea rezidurilor menajere.

Planşa 11. Oraşul de Floci, grindul nr. 3.

Planşa 12. Oraşul de Floci, grind nr. 8. Planul general al secţiunilor.

Planşa 13. Oraşul de Floci, grind nr. 8.

Planşa 14. Oraşul de Floci, grind nr. 8. Mormintele M1, M2.

Planşa 15. Oraşul de Floci, grind nr. 8. Ceramică smălţuită şi otomană.

Planşa 16. Oraşul de Floci, grind nr. 8. Ceramică smălţuită şi otomană.

\section{AUTORI}

dr. Anca Păunescu

Muzeul Naţional de Istorie a României

Calea Victoriei 12, sector 3, Bucureşti, 030026

Tel. 021.315.82.07

ROMÂNIA

e-mail: anca_paunescu45@yahoo.com

\section{drd. Irina Ene}

Muzeul Naţional de Istorie a României

Calea Victoriei 12, sector 3, Bucureşti, 030026

Tel. 021.315.82.07

ROMÂNIA

e-mail: irinaene29@yahoo.com

\section{dr. Dana Mihai}

Institutul Naţional al Monumentelor Istorice

Str. Zossima Demarat 8, sector 3, Bucureşti

Tel. 021.327.09.18

Tel/fax 021.327.09.19

ROMÂNIA

e-mail: evidenta@inmi.ro

\section{dr. Gheorghe Matei}

Muzeul Judeţean Ialomiţ̧a

Str. Matei Basarab, 30, Slobozia, jud. Ialomiţa

Tel. 0243.230.054.

ROMÂNIA

e-mail: gica_matei@yahoo.com 


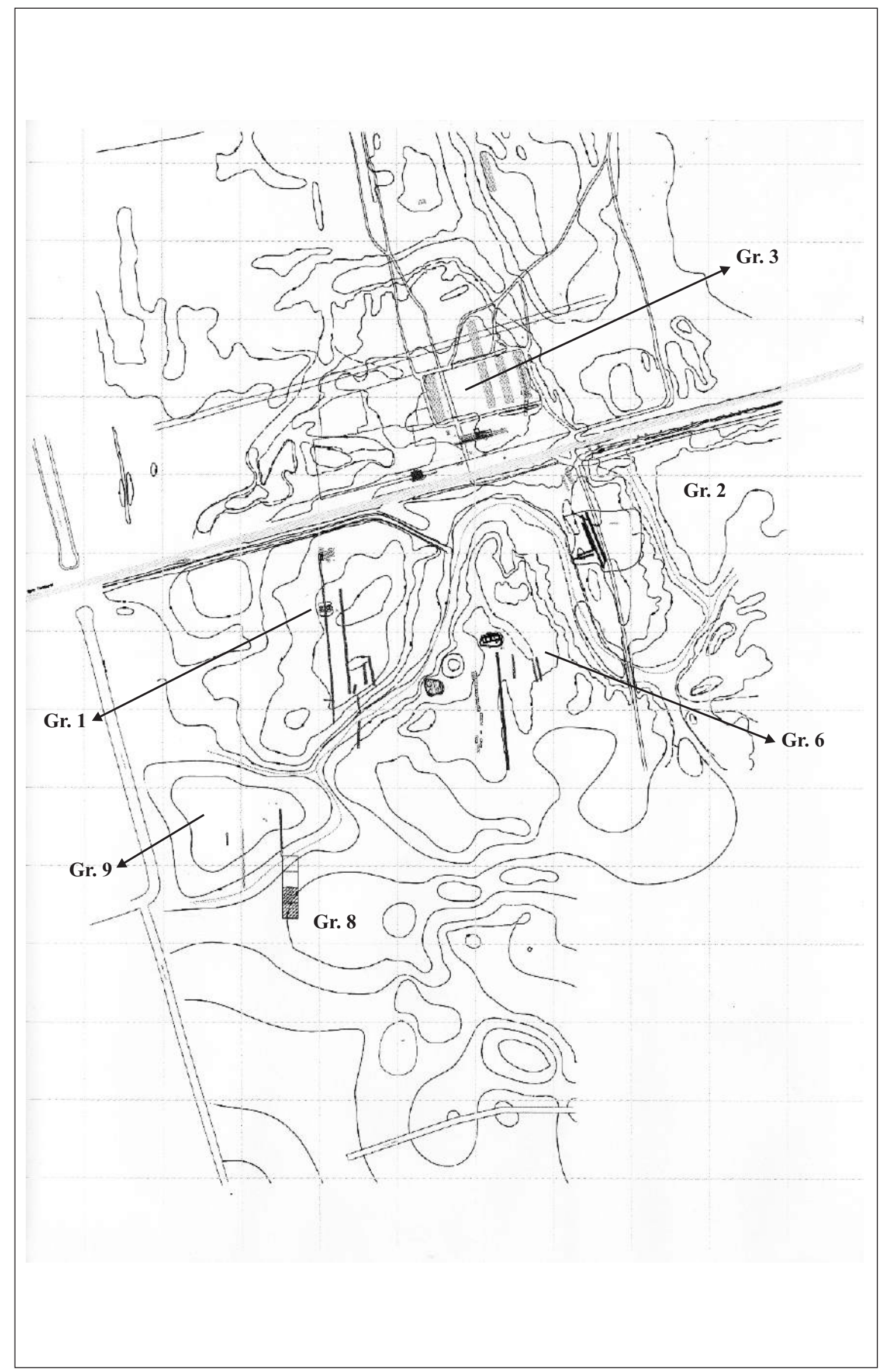

Pl 1. Oraşul de Floci, planul general al grindurilor. 


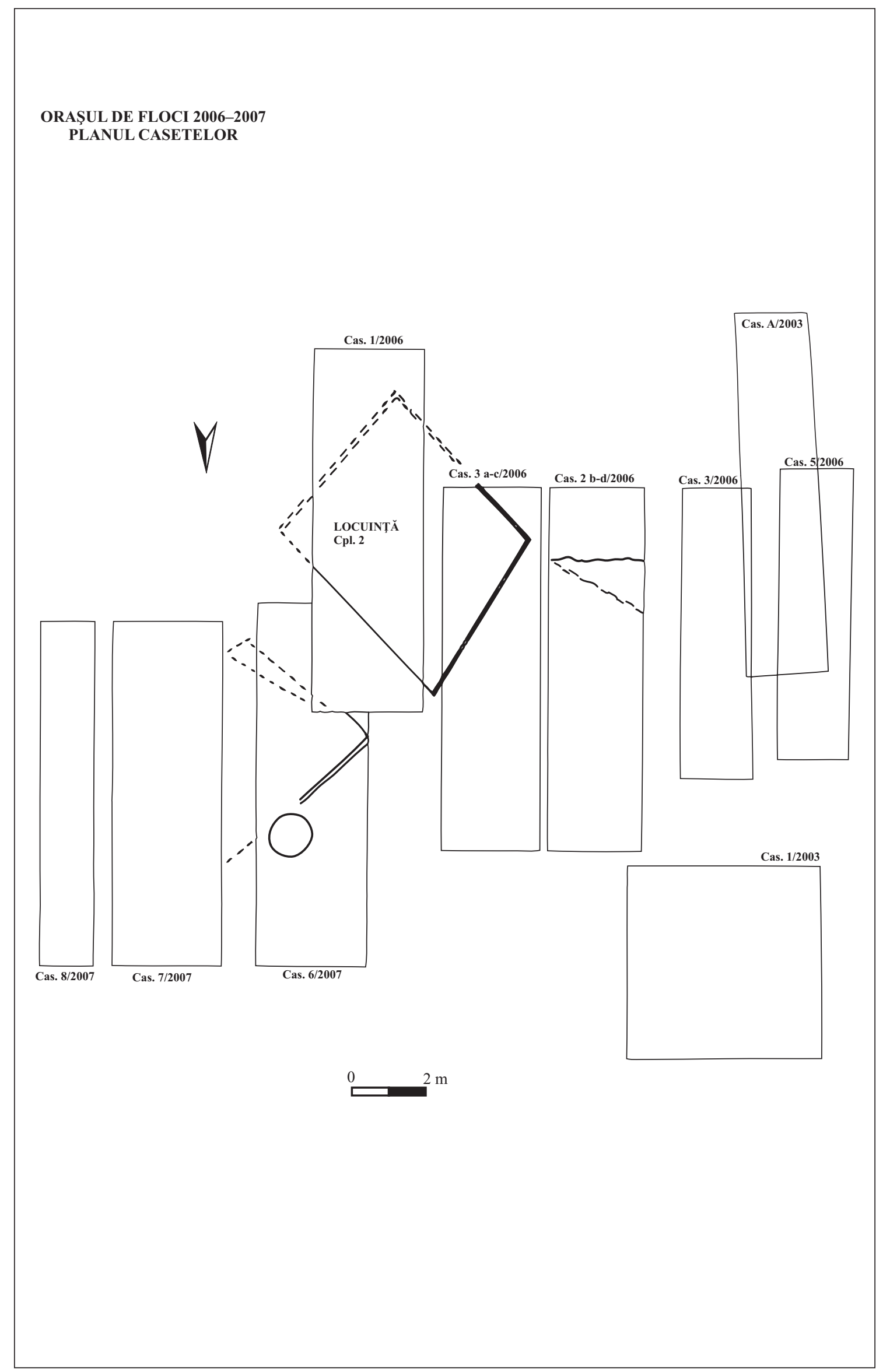

PI. 2. Oraşul de Floci, grind nr. 1, planul casetelor. 


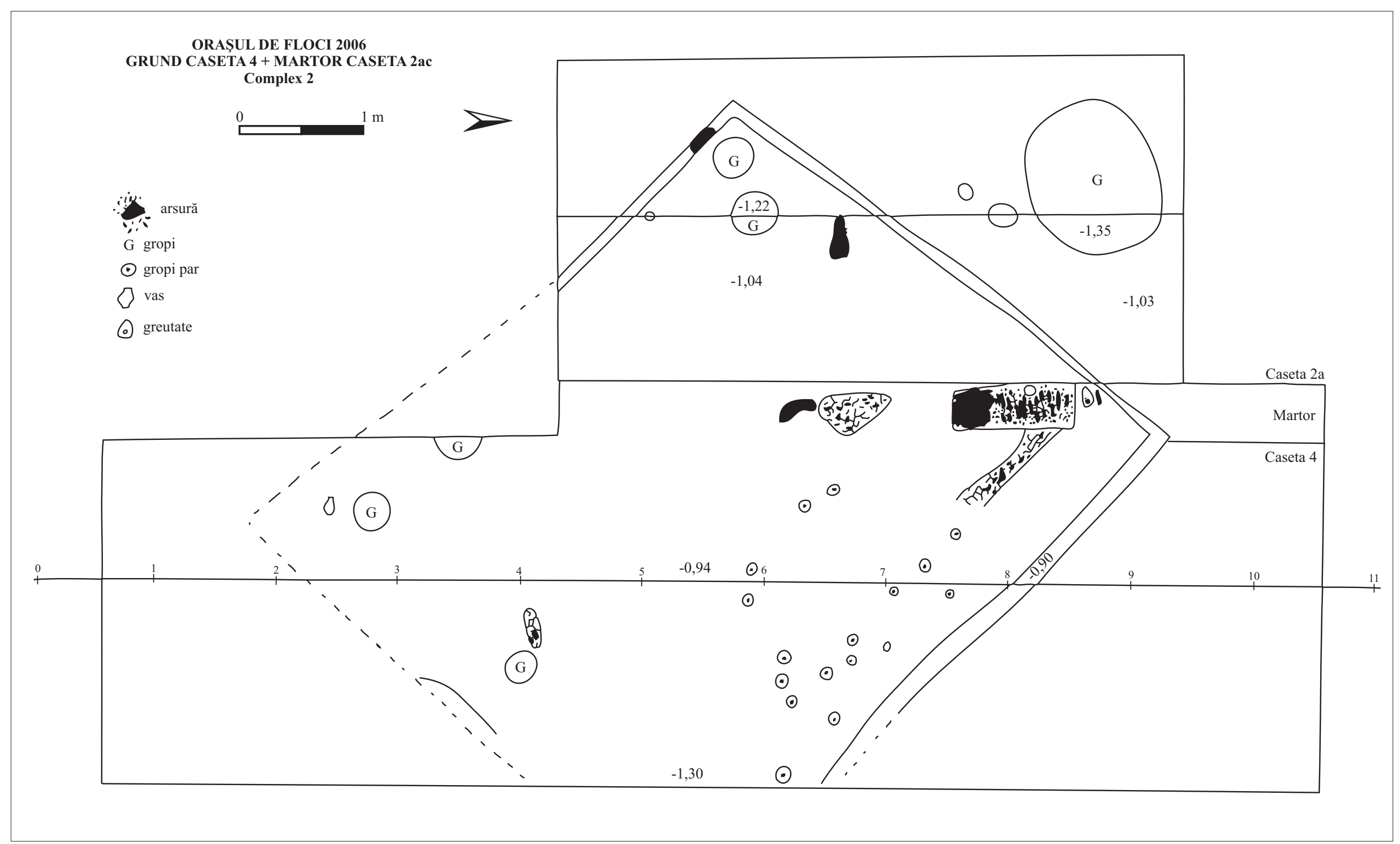

PI. 3. Oraşul de Floci, grind nr. 1, planul complexului nr. 2 - locuinţa 1/2006. 


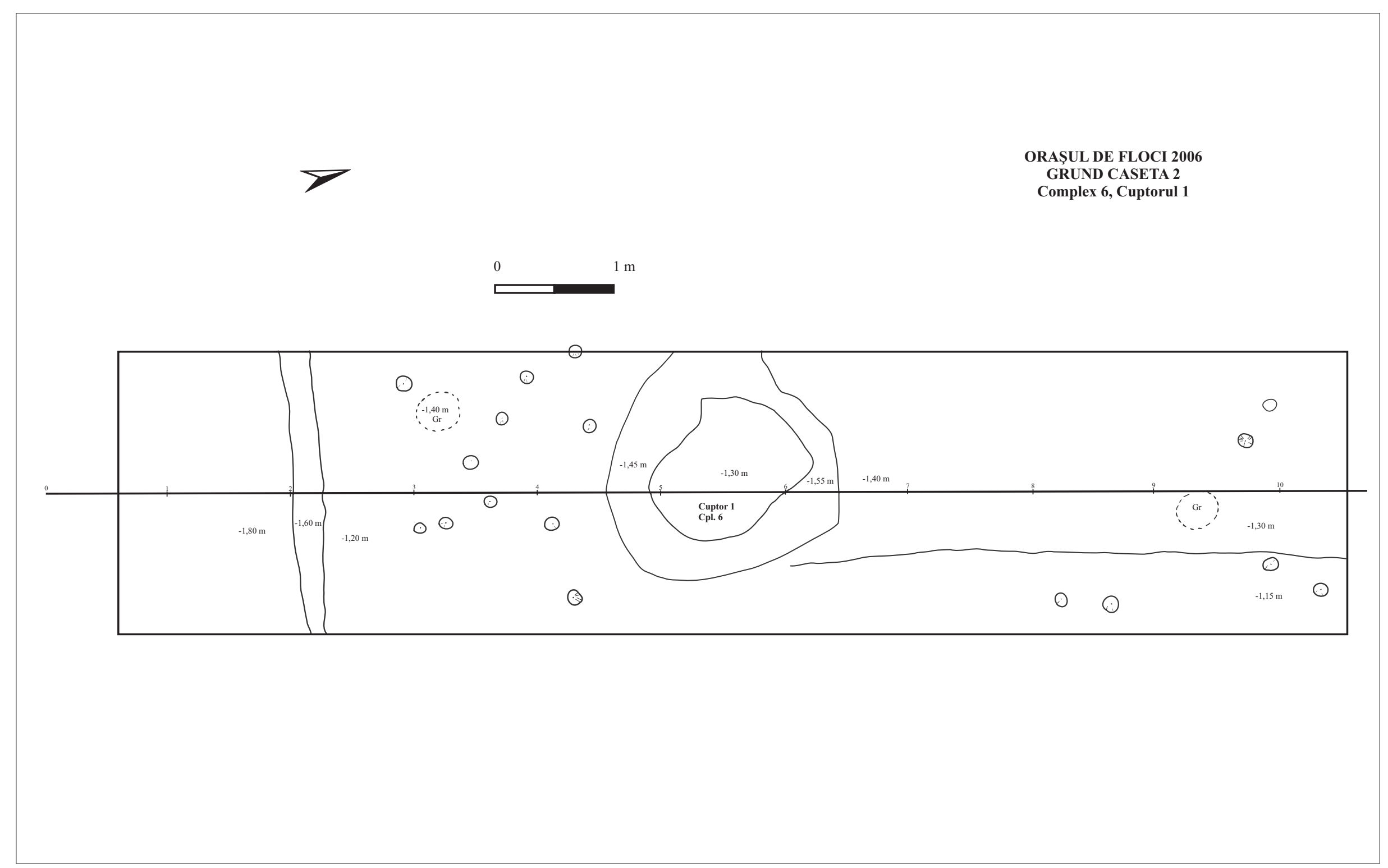

Pl. 4. Oraşul de Floci, grind nr. 1, planul complexului nr. 6, cuptor. 


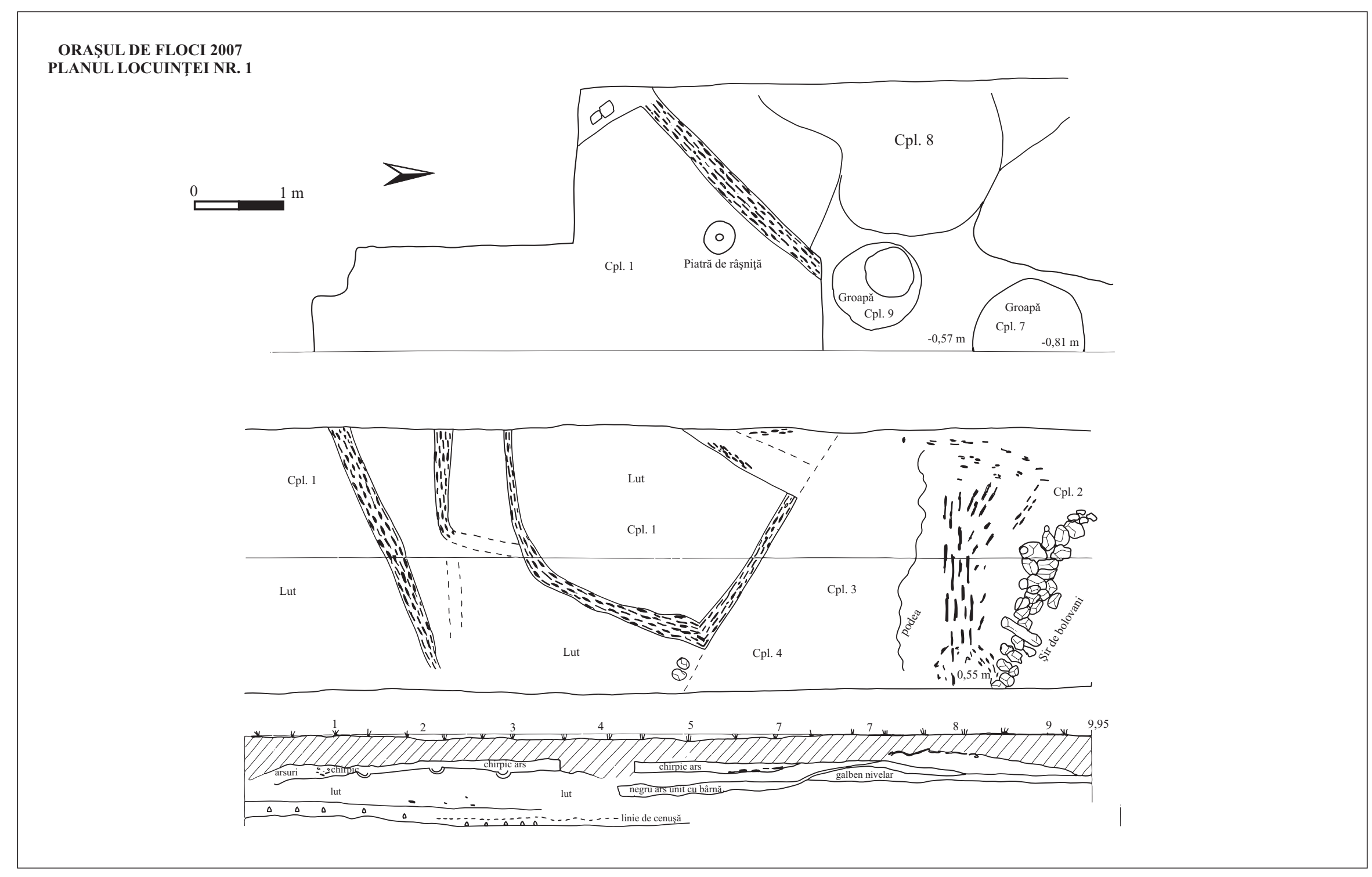

Pl. 5. Oraşul de Floci, grind nr. 1, planul complexului nr. 1, locuinţa nr. 1/2007. 


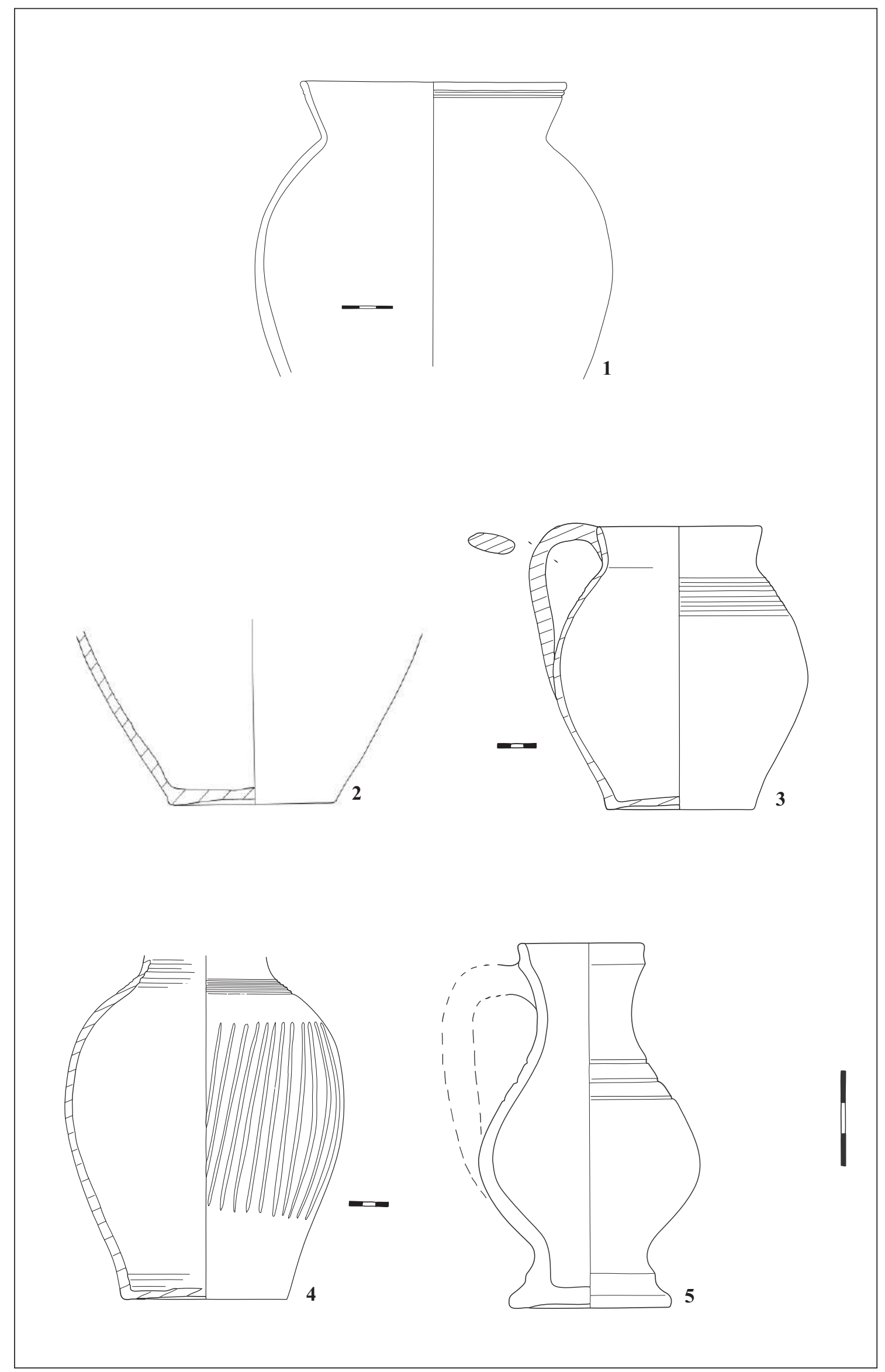

PI. 6. Oraşul de Floci, grindul nr. 1, ceramică nesmălţuită, secolul al XVI-lea. 


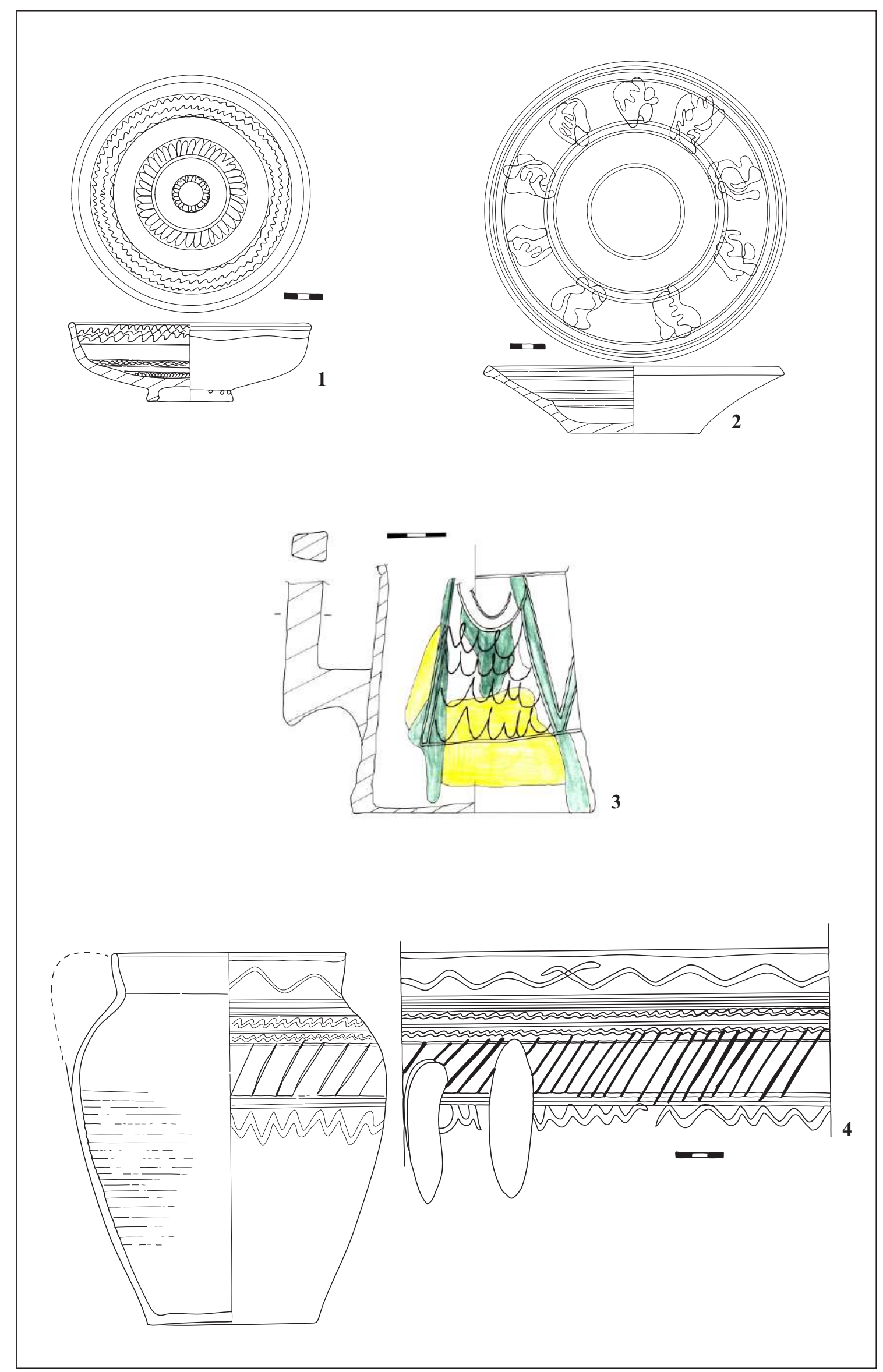

PI. 7. Oraşul de Floci, grindul nr. 1, ceramică smălţuită. 


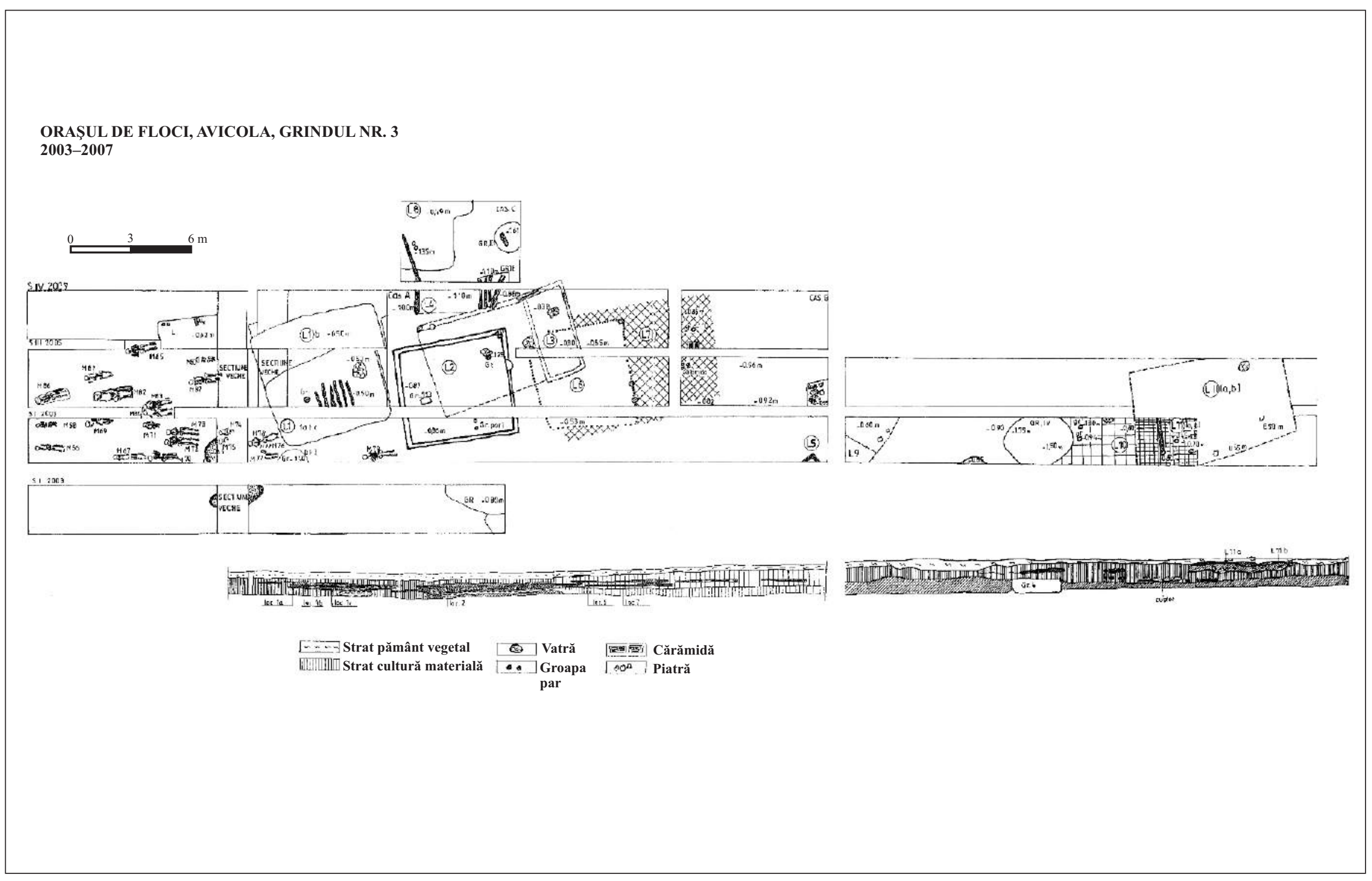

PI. 8. Oraşul de Floci, grindul nr. 3. 
ORAȘUL DE FLOCI, 2007, S I

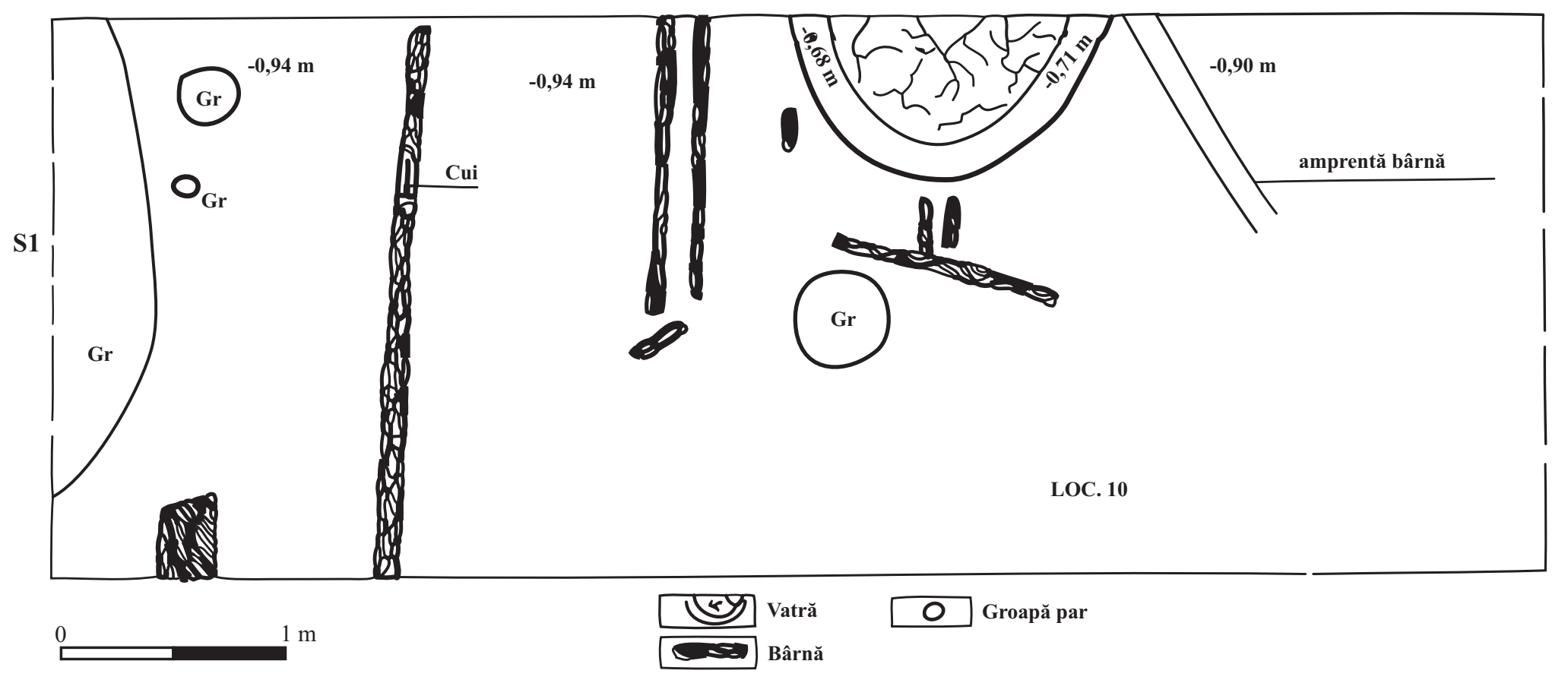

Pl. 9. Oraşul de Floci, grindul nr. 3, planul grund al locuinţei nr. 10/2007 


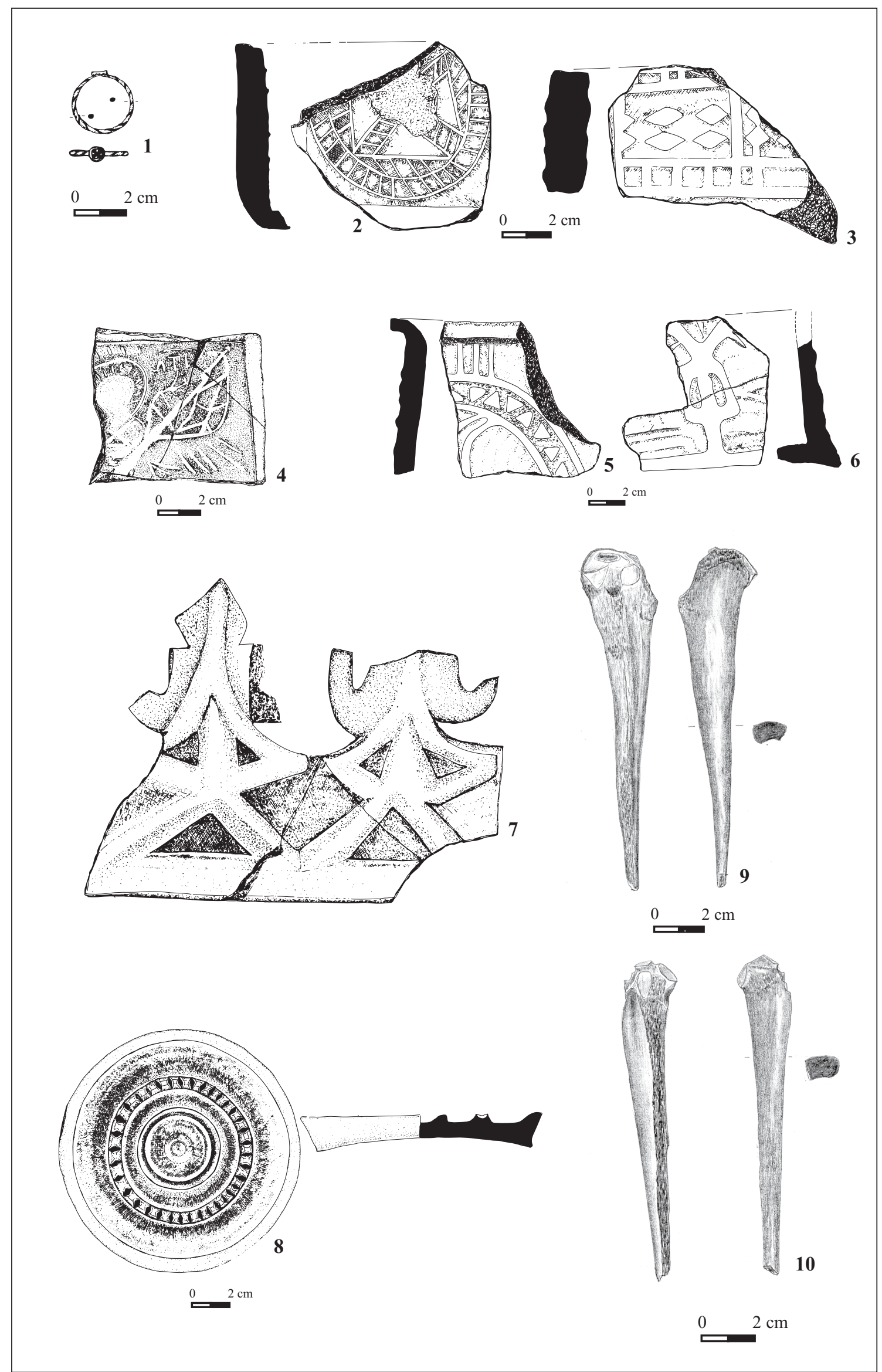

Pl. 10. Oraşul de Floci, grind 3, ceramică decorativă şi obiecte de uz casnic descoperite în locuinţe şi gropi pentru depozitarea rezidurilor menajere 


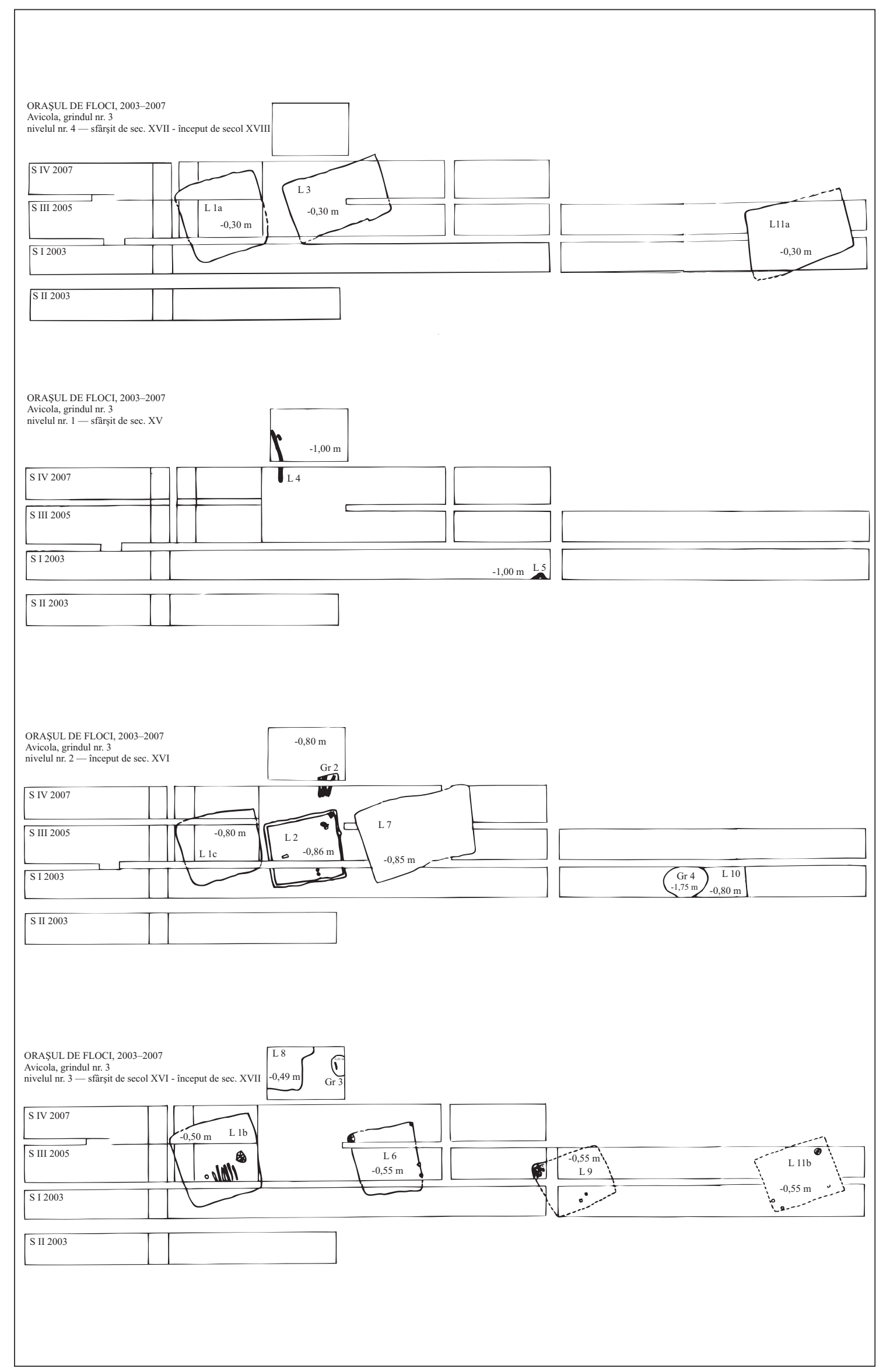

Pl. 11. Oraşul de Floci, grindul nr. 3. 


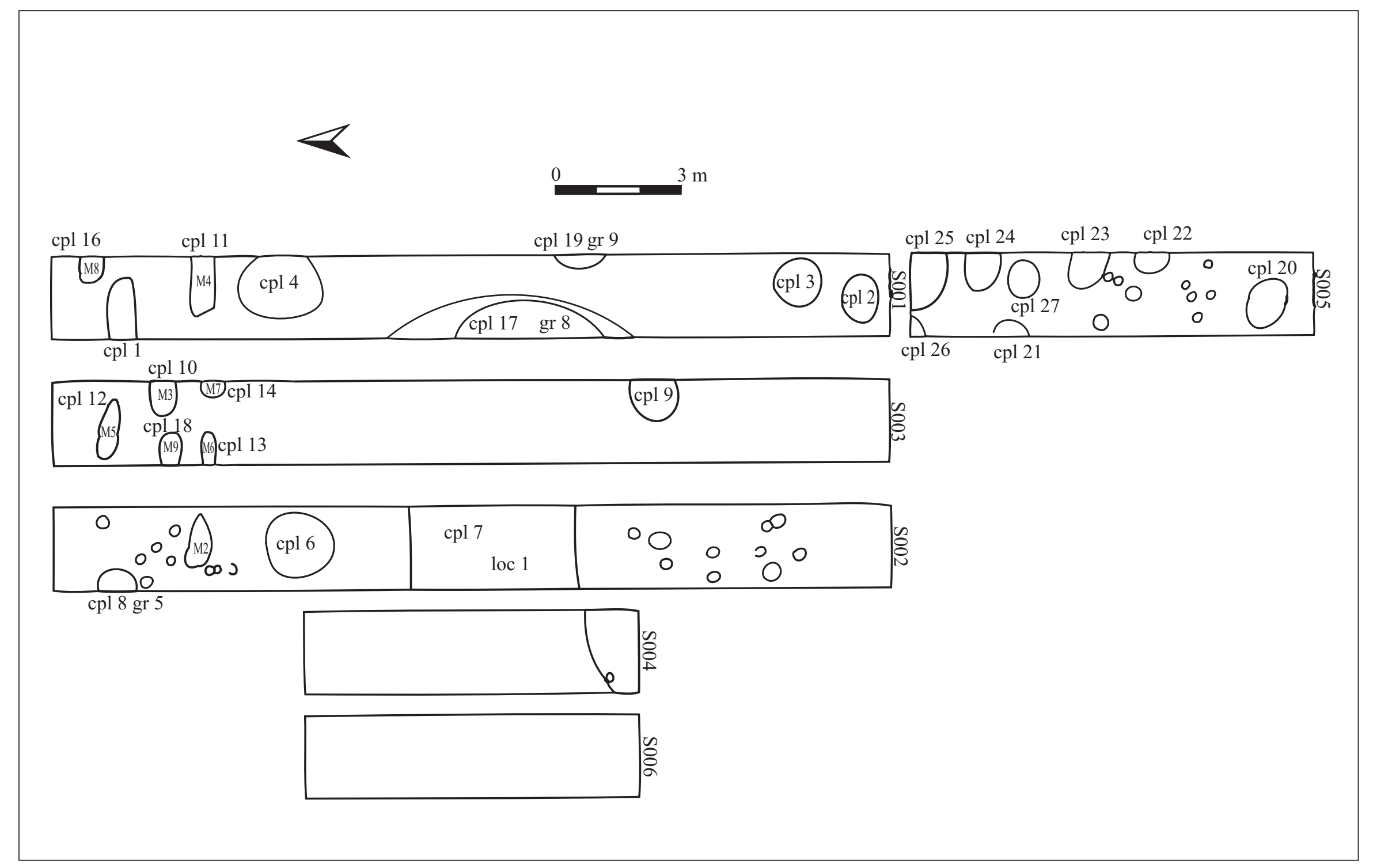

Pl. 12. Oraşul de Floci, grindul nr. 8, planul general al secţiunilor. 




Pl. 13. Oraşul de Floci, grind 8. 


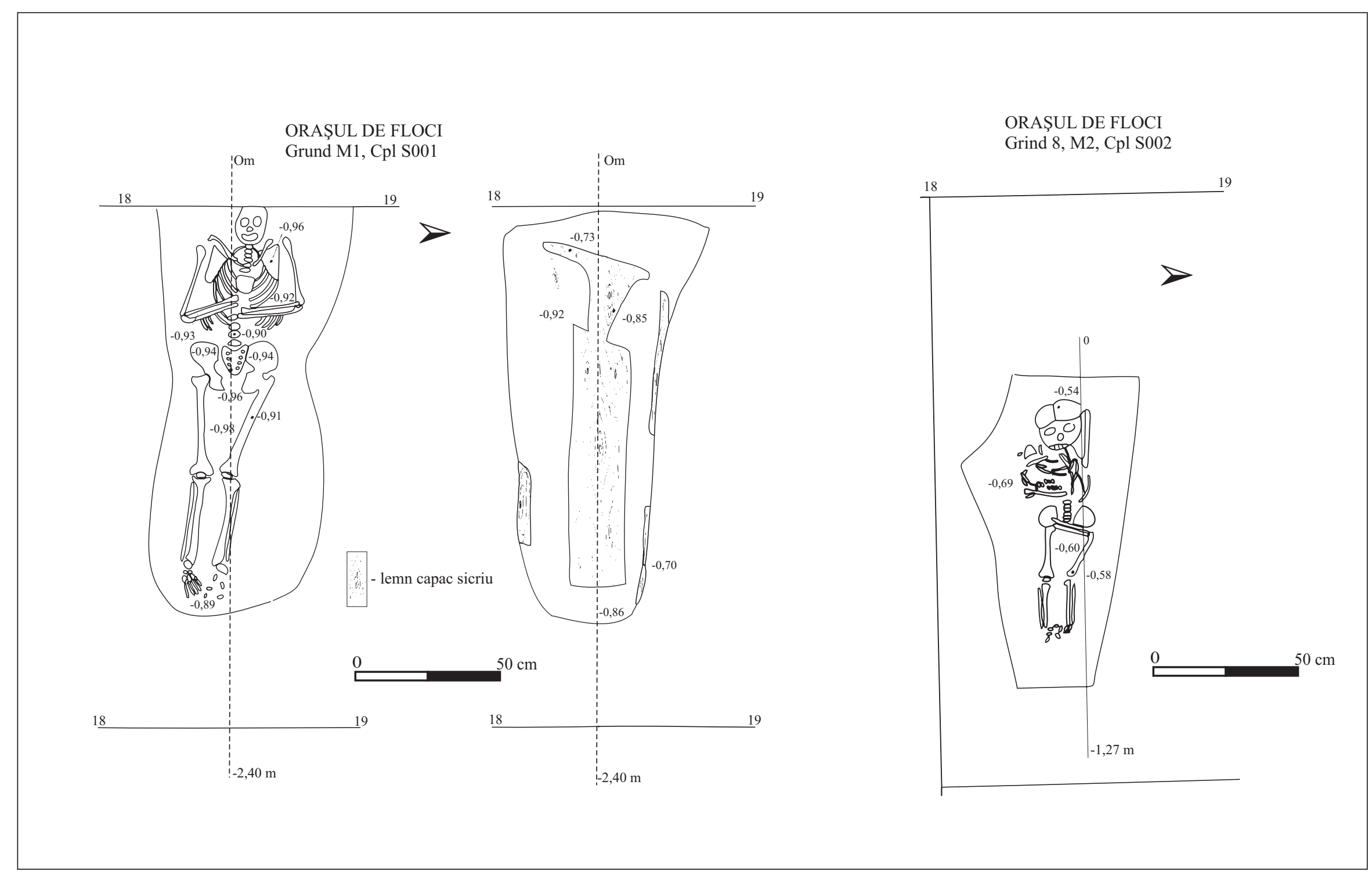

Pl. 14. Oraşul de Floci, grind nr. 8. Mormintele M1, M2. 


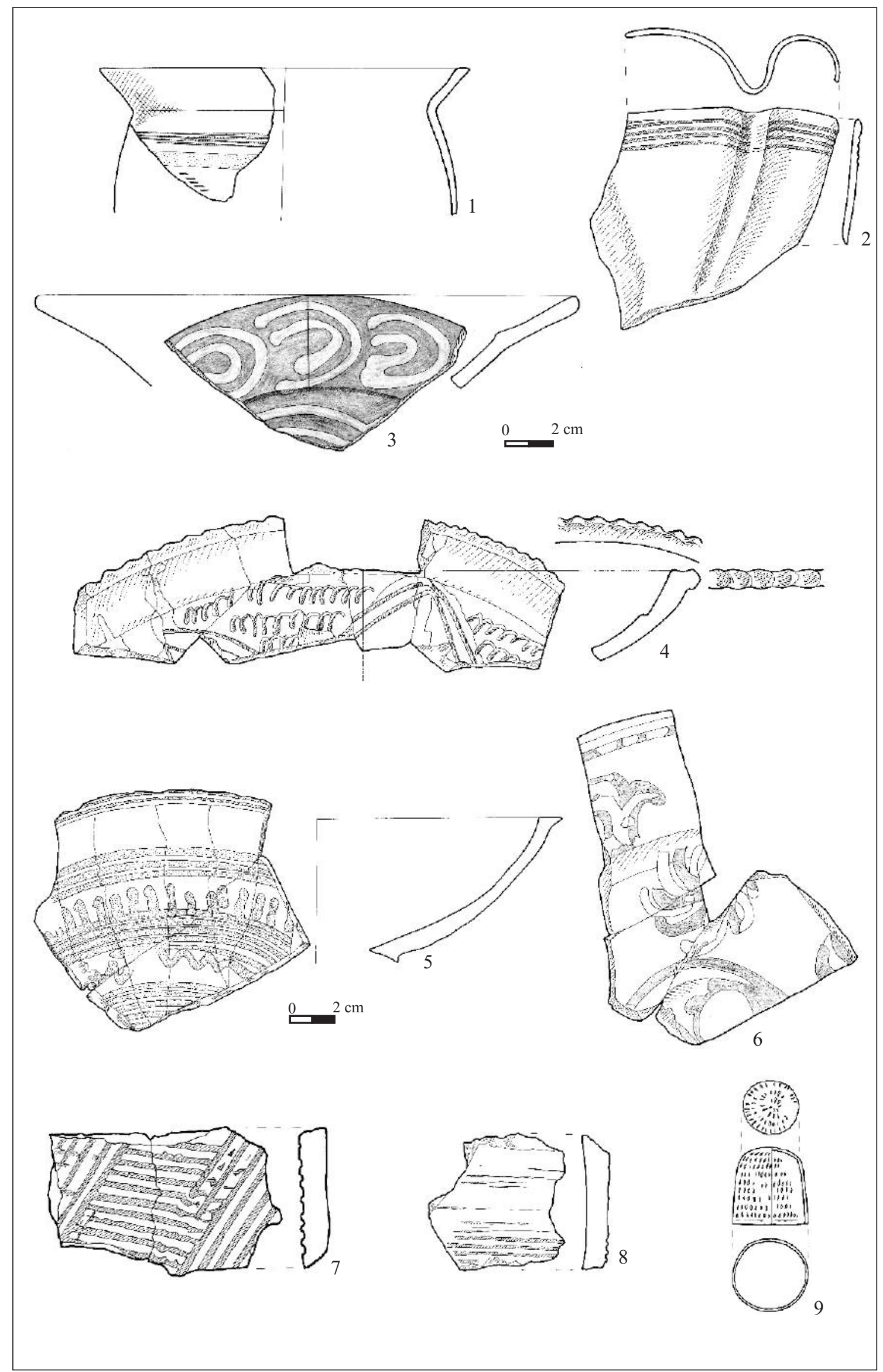

Pl. 15. Oraşul de Floci. Grindul nr. 8. Ceramică smălţuită şi otomană. 

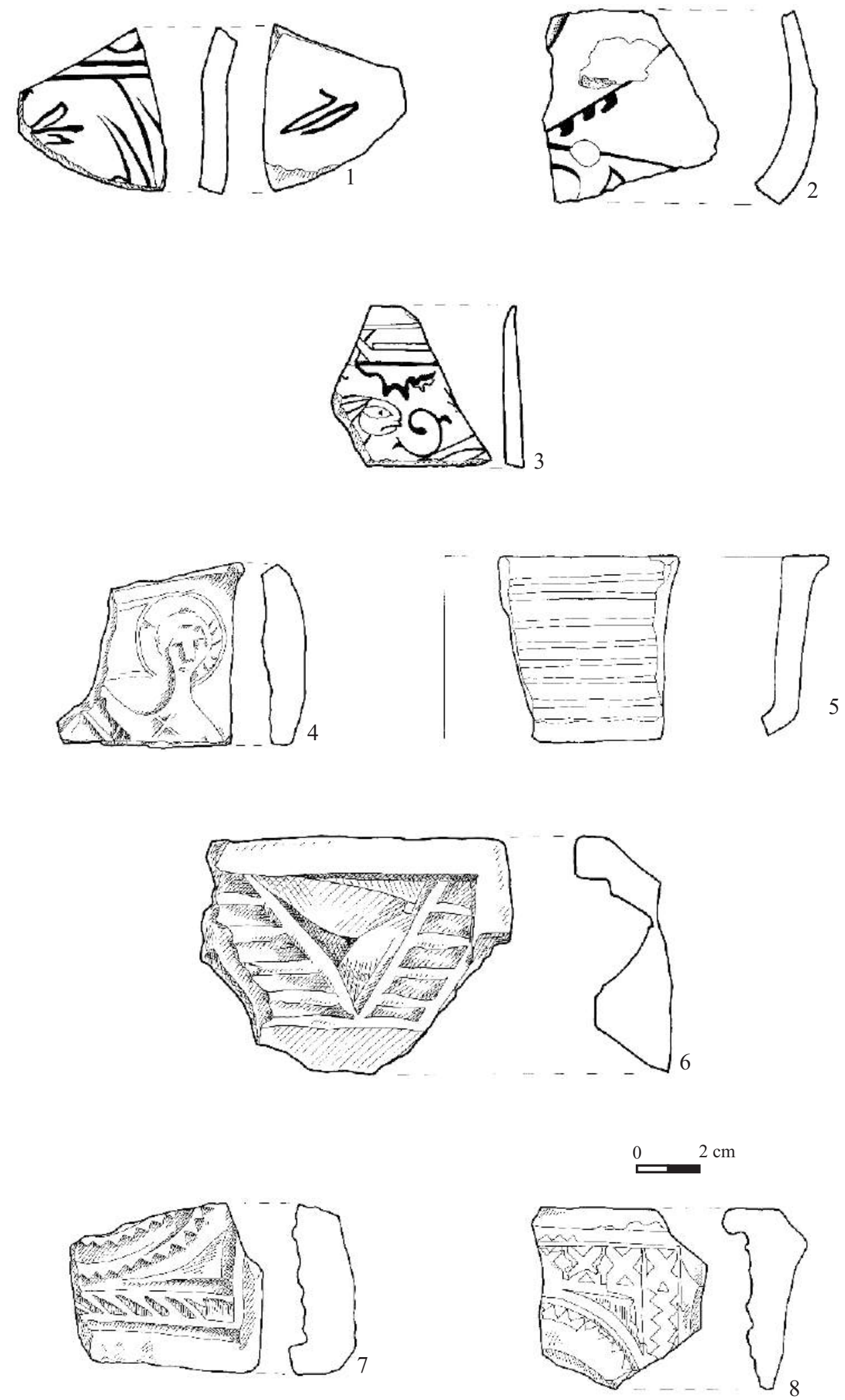

Pl. 16. Oraşul de Floci. Grindul nr. 8. Ceramică smălţuită şi otomană. 